\title{
Medicago truncatula and Glomus intraradices gene expression in cortical cells harboring arbuscules in the arbuscular mycorrhizal symbiosis
}

\author{
S Karen Gomez ${ }^{1}$, Hélène Javot ${ }^{1}{ }^{1}$, Prasit Deewatthanawong ${ }^{1}$, Ivone Torres- \\ Jerez $^{2}$, Yuhong Tang ${ }^{2}$, Elison B Blancaflor ${ }^{2}$, Michael K Udvardi ${ }^{2}$ and \\ Maria J Harrison*1
}

\begin{abstract}
Address: ${ }^{1}$ Boyce Thompson Institute for Plant Research, Tower Road, Ithaca, NY 14853, USA, 2 Plant Biology Division, Samuel Roberts Noble Foundation, 2510 Sam Noble Parkway, Ardmore, OK 73401, USA and ${ }^{3} \mathrm{CEA} /$ Cadarache IBEB, Service de Biologie Végétale et de Microbiologie Environnementales, UMR 6191 CNRS-CEA-Aix Marseille Univ., F-13108 St. Paul Lez Durance, France

Email: S Karen Gomez - skg34@cornell.edu; Hélène Javot - helene.javot@laposte.net; Prasit Deewatthanawong - pd72@cornell.edu; Ivone Torres-Jerez - itjerez@noble.org; Yuhong Tang - ytang@noble.org; Elison B Blancaflor - eblancaflor@noble.org;

Michael K Udvardi - mudvardi@noble.org; Maria J Harrison* - mjh78@cornell.edu

* Corresponding author
\end{abstract}

Published: 22 January 2009

BMC Plant Biology 2009, 9:10 doi:10.1 186/1471-2229-9-10

This article is available from: http://www.biomedcentral.com/I47I-2229/9/10

(c) 2009 Gomez et al; licensee BioMed Central Ltd.

This is an Open Access article distributed under the terms of the Creative Commons Attribution License (http://creativecommons.org/licenses/by/2.0), which permits unrestricted use, distribution, and reproduction in any medium, provided the original work is properly cited.

\begin{abstract}
Background: Most vascular flowering plants have the capacity to form symbiotic associations with arbuscular mycorrhizal (AM) fungi. The symbiosis develops in the roots where AM fungi colonize the root cortex and form arbuscules within the cortical cells. Arbuscules are enveloped in a novel plant membrane and their establishment requires the coordinated cellular activities of both symbiotic partners. The arbuscule-cortical cell interface is the primary functional interface of the symbiosis and is of central importance in nutrient exchange. To determine the molecular events the underlie arbuscule development and function, it is first necessary to identify genes that may play a role in this process. Toward this goal we used the Affymetrix GeneChip ${ }^{\circledR}$ Medicago Genome Array to document the M. truncatula transcript profiles associated with AM symbiosis, and then developed laser microdissection (LM) of M. truncatula root cortical cells to enable analyses of gene expression in individual cell types by RT-PCR.

Results: This approach led to the identification of novel $M$. truncatula and $G$. intraradices genes expressed in colonized cortical cells and in arbuscules. Within the arbuscule, expression of genes associated with the urea cycle, amino acid biosynthesis and cellular autophagy was detected. Analysis of gene expression in the colonized cortical cell revealed up-regulation of a lysine motif (LysM)-receptor like kinase, members of the GRAS transcription factor family and a symbiosis-specific ammonium transporter that is a likely candidate for mediating ammonium transport in the AM symbiosis.

Conclusion: Transcript profiling using the Affymetrix GeneChip ${ }^{\circledR}$ Medicago Genome Array provided new insights into gene expression in $M$. truncatula roots during AM symbiosis and revealed the existence of several $G$. intraradices genes on the $M$. truncatula GeneChip ${ }^{\circledR}$. A laser microdissection protocol that incorporates low-melting temperature Steedman's wax, was developed to enable laser microdissection of $M$. truncatula root cortical cells. LM coupled with RT-PCR provided spatial gene expression information for both symbionts and expanded current information available for gene expression in cortical cells containing arbuscules.
\end{abstract}




\section{Background}

The arbuscular mycorrhiza is the name given to a symbiotic association of plants and arbuscular mycorrhizal (AM) fungi. The AM symbiosis occurs widely throughout the plant kingdom and involves angiosperms, gymnosperms, pteridophytes and some bryophytes. The fungi that participate in this symbiosis are all members of the Glomeromycota, [1-3], a likely sister group to the Ascomycota and Basidiomycota. The symbiosis develops in the plant roots, where AM fungi form extensively branched hyphae, called arbuscules, in the cortical cells. In addition to growth within the root, the fungus develops a network of extra-radical hyphae that extends into the rhizosphere. Inorganic phosphate $(\mathrm{Pi})$ and nitrogen $(\mathrm{N})$, acquired by the extra-radical hyphae, are translocated to the arbuscules and released to the plant. In return the plant provides the fungus with carbon. $\mathrm{P}$ and $\mathrm{N}$ are the two mineral nutrients that plants require in the greatest quantities and therefore the symbiosis has an important influence on plant health and consequently on ecosystem function [4$6]$.

There has been significant progress in understanding the signaling associated with the early stages of development of AM symbiosis [7]. Some of the signal molecules have been identified, including strigolactones, which act as precontact signals to stimulate AM fungal growth and metabolism $[8,9]$. In addition, several components of a plant 'symbiosis signaling' pathway required for fungal entry into the root have been cloned [10-17]. These genes were identified initially in legumes, where the symbiosis signaling pathway is required also for the interaction with rhizobia. However, orthologs of these genes have been identified in tomato and rice, where they are required for AM symbiosis [18,19]. This further supports the hypothesis that the symbiosis signaling pathway arose initially for interactions with AM fungi, and in legumes it was coopted to enable interactions with rhizobia [19-21]. Currently, for AM symbiosis, the downstream genes controlled by this pathway are not known. In general, events associated with fungal development in the cortex are less well understood, and genes controlling arbuscule formation, have yet to be identified. Arbuscule development is an active process for both symbionts. The fungal hypha penetrates the cortical cell wall and undergoes repeated dichotomous branching, while the plant cell undergoes significant cellular changes, including reorganization of the cytoskeleton, endoplasmic reticulum and development of the peri-arbuscular membrane, which envelops the arbuscule [22-26]. Reorganization of the cytoskeleton and endoplasmic reticulum is initiated prior to arbuscule formation suggesting that a mobile signal may trigger these events [26,27]. Currently, information about the lipid and protein content of the peri-arbuscular membrane is limited, but it is clear that the membrane contains some unique proteins, including symbiosis-specific Pi transporters that function to import Pi into the cortical cell [28]. The transporters involved in $\mathrm{N}$ acquisition are as yet unknown, but a series of nuclear magnetic resonance (NMR) spectroscopy and gene expression studies indicate that the fungus assimilates $\mathrm{N}$ in the external hyphae, translocates this to the intra-radical hyphae as arginine, and then disassembles the arginine to retain the carbon molecules, while providing $\mathrm{N}$ to the plant, probably as ammonium $\left(\mathrm{NH}_{4}^{+}\right)$[29-31]. Although not shown directly, it is likely that $\mathrm{NH}_{4}{ }^{+}$transfer to the plant occurs at the arbuscule-cortical cell interface also.

Arbuscules are terminally differentiated hyphae with a finite life and following development, they undergo a degeneration phase in which the arbuscule branches collapse, and the arbuscule gradually disappears from the cell $[22,32-34]$. This process is not well understood, but it is clear that arbuscule development and degeneration occur cell autonomously and arbuscules in neighboring cells may be in different phases of the life cycle. Although the arbuscule-cortical cell interface is central to the AM symbiosis, currently, we understand little of the processes that enable its development or that control its degeneration.

To gain insight into the molecular changes that accompany development of AM symbiosis, a variety of transcript profiling approaches have been undertaken. In rice, surveys using a whole genome chip identified mycorrhizaresponsive genes and revealed a partial overlap in the transcriptional responses to mutualistic and pathogenic biotrophic fungi [35]. In Medicago truncatula, suppressive subtractive hybridization, cDNA arrays and long oligonucleotide arrays have been used to document transcript changes associated with AM symbiosis [36-40]. The inclusion of $M$. truncatula symbiosis mutants enabled gene expression to be associated with different phases of the symbiosis, for example appressoria formation [41]. A mycorrhizal root includes a heterogeneous mix of colonized and non-colonized cells, and therefore spatial gene expression information is particularly important. In situ hybridization and/or analysis of promoter-reporter fusions demonstrated that genes whose expression was induced in colonized roots could be further separated into two groups; those expressed exclusively in cells containing arbuscules and those expressed in cells containing arbuscules and in neighboring non-colonized cells $[28,36,38,42-46]$. These data indicate that the different cortical cells of the mycorrhizal root system have unique transcript profiles, and point to at least two signaling pathways active in regulating mycorrhiza-induced gene expression. While these approaches have advanced information about gene expression in colonized cortical cells, in situ hybridization or promoter-reporter gene studies are labor intensive and this precludes surveys of a large 
number of genes. Our current knowledge of genes expressed in cells containing arbuscules is limited to less than 35 genes. In addition, the genes that have been analyzed are those that have the highest transcript levels and relatively few receptors or transcriptional regulators have been investigated. Beyond plant gene expression in the colonized cortical cell, almost nothing is known about gene expression in the arbuscule.

Laser microdissection (LM) offers a new way to obtain RNA from a subset of cells, and coupled with transcript profiling approaches, it provides an opportunity to monitor gene expression in an individual cell type more easily than promoter-reporter gene fusions. LM was originally developed to isolate specific animal cells from complex tissues; a breakthrough for cancer and neuronal research $[47,48]$. In plants, LM was used initially to isolate phloem cells from rice leaves [49]. Subsequently, epidermal and vascular tissues were isolated from maize coleoptiles [50] and then various cell or tissue types, including bundle sheath, shoot tip protoderm, shoot apical meristem, leaf primordium, seedling procambium, hypocotyls and root meristems have been harvested from maize, rice, radish and tomato [51,52]. So far, most studies have focused on shoot tissues. In a few cases, LM has been used to isolate plant cells during interactions with other organisms including cyst or root-knot nematode feeding sites in soybean roots [53-57]. In addition, fungus-plant interactions were assessed in maize by dissecting parenchyma cells infected with Colletotrichum graminicola and the RNA samples were used for analysis of $C$. graminicola gene expression [58]. Recently, this technology was used to isolate cells from arbuscular mycorrhizal or non-mycorrhizal tomato roots [59] where it enabled the analysis of phosphate transporter gene expression in the plant and the fungus.

Toward the ultimate goal of understanding how arbuscules develop, we initiated experiments to identify genes expressed in cortical cells containing arbuscules. We first undertook a profiling experiment with a new $M$. truncatula GeneChip ${ }^{\varpi}$, and then developed LM of M. truncatula root cortical cells to enable cell-type specific analyses of gene expression by RT-PCR. This approach led to the identification of novel plant and fungal genes expressed in colonized cortical cells and in arbuscules, including members of the LysM-receptor like kinase family, GRAS transcription factor family, a novel ammonium transporter that is a strong candidate for mediating symbiotic ammonium transport, and AM fungal genes of the urea cycle.

\section{Results \\ Use of the Medicago GeneChip ${ }^{\circledR}$ to monitor transcript profiles in M. truncatula colonized by Glomus intraradices}

Previously in M. truncatula, a long oligonucleotide-based array containing 16,000 features, was used to profile gene expression in a number of different AM symbioses $[38,39]$. While these studies provided important insights into gene expression during the AM symbiosis, they surveyed only a small fraction of the $M$. truncatula transcriptome. In order to expand these gene expression studies, we used the Affymetrix Medicago GeneChip ${ }^{\circledast}$. It contains 61,278 probe sets of which 32,167 were designed based on sequences from the M. truncatula EST database and 18,733 were based on gene predictions from the International Medicago Genome Annotation Group (IMGAG) http://www.affymetrix.com. The GeneChip ${ }^{\circledR}$ was hybridized with three biological replicate RNA samples from $M$. truncatula and M. truncatula/G. intraradices mycorrhizal roots and using significance criteria established previously $[60], 652$ genes that showed a 2 -fold or greater change in gene expression in mycorrhizal roots relative to the mockinoculated controls were identified. Of these, 637 genes showed increased transcript levels in G. intraradices-colonized roots, and 15 genes showed decreased transcript levels (Additional file 1). Our previous experiments with the M. truncatula $16 \mathrm{~K}$ array had identified 110 genes that showed a 2-fold or greater change in gene expression [39]. 82 induced genes were present in both data sets [39]. Thus, the GeneChip dataset has extended the transcriptional information available for M. truncatula/G. intraradices mycorrhizal roots substantially.

New AM-induced genes with potentially important roles in the symbiosis include an ammonium transporter (IMGAG|1723.m00046), which shows a 4.8 fold induction in mycorrhizal roots (Table 1). This transporter is a candidate for mediating symbiotic $\mathrm{N}$ transport. Other transporters including a zinc transporter (AJ499751, 7.6 fold), organic-cation transporter (TC98622, 2.5 fold), and copper transport protein (TC97522, 50 fold) were induced in mycorrhizal roots, along with genes encoding transporters of the peptide transporter family (AL377202, TC97569, AL387494, and BE998753) and ABC transporter family (AL382570, IMGAG|1050.m00013, IMGAG|733.m00003， IMGAG|1088.m00025, AW287942, BG644663, TC109985, TC96634, IMGAG|795.m00013).

Carbon metabolism and carbon transport in the AM symbiosis are also areas of great importance that are currently poorly understood. A putative alpha-amylase gene (IMGAG|1739.m00052) was up-regulated 2.2 fold suggesting a potential increase in starch breakdown. Also, a putative SNF1-related protein kinase gene (AW573798) 
Table I: Gene expression data for genes selected for analysis in the LM cell samples.

\begin{tabular}{|c|c|c|c|c|}
\hline & \multirow[b]{2}{*}{ Annotation } & \multicolumn{3}{|c|}{ Array data } \\
\hline & & Ratio' (Mt/Gi-Mt) & P-Value & q-Value \\
\hline \multicolumn{5}{|c|}{ M. truncatula Genes } \\
\hline TCI0085I & MtNIPI & $|5.7|$ & 0 & 0.030 \\
\hline TCI0I391 & Bark lectin II precursora & 72.70 & 0 & 0.084 \\
\hline TCI07070 & Blue copper-binding protein-like $\mathrm{e}^{\mathrm{a}}$ & 162.37 & 0 & 0.164 \\
\hline TC98064 & Cysteine-rich antifungal protein 2 precursor & 47.05 & 0 & 0.030 \\
\hline TCI01060 & Defensin AMPI & 130.10 & 0 & 0.029 \\
\hline TCI06954 & $\mathrm{MtSCPI}$ & 29.94 & 0 & 0.044 \\
\hline TCI0I627 & Transfactor-like protein & 195.78 & 0 & 0.030 \\
\hline TC94453 & MtPT4 & 158.20 & 0 & 0.030 \\
\hline AJ499899 & GRAS family member & 99.58 & 0 & 0.054 \\
\hline TC97569 & Peptide transporter & 7.21 & 0 & 0.028 \\
\hline TCI08660 & GDSL-motif lipase/hydrolase-like protein & 9.24 & 0 & 0.038 \\
\hline TC9927I & Palmitoyl-acyl carrier protein thioesterase & 49.41 & 0 & 0.064 \\
\hline II97.m000I5 & $M t L Y R I$ & 3.65 & 0 & 0.091 \\
\hline AL386880 & GRAS family member & 7.41 & $1.6 \mathrm{E}-17 \mathrm{I}$ & 0.072 \\
\hline TCII073I & Triacylglycerol/steryl ester lipase-like protein & 102.45 & 0 & 0.157 \\
\hline TC97522 & Copper transport protein & 50.49 & 0 & 0.035 \\
\hline TC104979 & Dihydrodipicolinate synthase & 15.55 & 0 & 0.030 \\
\hline 906.m00010 & Inositol polyphosphate related phosphatase & 4.46 & 0 & 0.112 \\
\hline AL387494 & Peptide transporter 2 & 6.73 & 0 & 0.043 \\
\hline AW573798 & SNFI-related protein kinase & 7.72 & 0 & 0.140 \\
\hline I 723.m00046 & Ammonium transporter & 4.78 & $4.4 \mathrm{E}-154$ & 0.110 \\
\hline \multicolumn{5}{|c|}{ Putative G. intraradices Genes } \\
\hline TCII 2506 & ADP-ribosylation factor & 25.84 & 0 & 0.036 \\
\hline TCI05524 & Probable autophagy protein AUT7 & 11.06 & 0 & 0.031 \\
\hline TCIII688 & Related to $\mathrm{p} 24$ protein & 38.10 & 0 & 0.029 \\
\hline AL3895II & Glutamine synthetase $^{a}$ & 118.80 & 0 & 0.043 \\
\hline TCI0503I & Arginase & 2.43 & 8.33E-39 & 0.135 \\
\hline TCI09807 & Probable ornithine aminotransferase & 4.20 & $1.6 \mathrm{E}-186$ & 0.111 \\
\hline AL387743 & Argininosuccinate synthase & 10.45 & 0 & 0.058 \\
\hline TCI00037 & Asparagine synthetase & 19.56 & 0 & 0.100 \\
\hline TCI06I86 & Probable acyl-CoA dehydrogenase & 10.66 & 0 & 0.031 \\
\hline AL382096 & Potential phospholipid-transporting ATPase DRS2 & 5.25 & 0 & 0.182 \\
\hline TCI05246 & Delta- 9 fatty acid desaturase & 140.11 & 0 & 0.030 \\
\hline
\end{tabular}

aGenes tested by RT-PCR have different ID

'Expression ratio for genes from the Medicago GeneChip ${ }^{\circledR}$ experiment that showed differential expression in $M$. truncatula roots colonized by $G$. intraradices relative to mock-inoculated control roots. For complete data set see Additional file I.

was up-regulated 7.7 fold (Table 1). The SNF1 and SNF1related kinases are widely conserved in eukaryotes and play a central role in sugar and energy signaling [61].

Two genes, one predicted to encode a protein involved in lipid biosynthesis, palmitoyl-ACP thioesterase, and one encoding an enzyme of lipid breakdown, a triacylglycerol/ steryl ester lipase (TC110731) were highly up-regulated. The latter showed a 102-fold increase in transcript levels (Table 1). This increase in both biosynthetic and degradative activities may be associated with the ongoing development and breakdown of the peri-arbuscular membrane associated with the different phases of the arbuscule lifespan.
Currently, transcription factors that regulate AM-induced gene expression are unknown. Here, 5 probesets representing members of the GRAS family of transcription factors (AL386879, AL386880, TC105118, IMGAG|1755.m00026 and AJ499899) indicate that several members of this gene family are up-regulated more than 7 -fold. Two GRAS family transcription factors are essential for nodulation $[62,63]$, and given the conserved symbiosis signaling pathway, there is a strong possibility that members of this family will be involved in regulating gene expression in AM symbiosis also. Other genes related to signaling or perception of signal, include a putative inositol polyphosphate phosphatase (IMGAG|906.m00010) that was up-regulated 4.4-fold 
(Table 1). Inositol polyphosphate 5-phosphatases are involved in the modulation of phosphoinositide signaling. In plants, inositol polyphosphate 5-phosphatases are members of large gene families and their individual roles are mostly unknown. While this signaling pathway has not been implicated in the AM symbiosis, lysophosphatidyl choline, was recently shown to induce expression of symbiotic Pi transporters in potato and tomato [64]. Finally, one of the most intriguing findings was a gene encoding a lysine motif-receptor-like kinase (LysM-RLK) called MtLYR1 [65] which showed a 3.6-fold increase in mycorrhizal roots (Table 1). MtLYR1 is a close relative of NFP, a LysM-RLK gene that is likely a Nod factor receptor $[65,66]$.

\section{Glomus intraradices genes are represented on the Medicago GeneChip ${ }^{\circledR}$}

The Medicago GeneChip includes 32,167 probes designed to sequences from the M. truncatula Gene Index http://compbio.dfci.harvard.edu. The Gene Index includes ESTs from mycorrhizal root cDNA libraries, consequently, there is the potential that some probes were designed, unintentionally, to ESTs that represent genes from the AM fungal symbionts. The discovery that some probes represent genes with BLAST hits exclusively to fungal sequences suggested that this may be the case. Therefore, we systematically mined the array data to identify probes that might represent AM fungal genes. Probes that showed an average expression value on the mock-inoculated arrays near background levels $(\leq 63)$ and a higher average expression value on $G$. intraradices-inoculated arrays, and corresponded to ESTs present exclusively in mycorrhizal cDNA libraries, were considered strong candidates. Subsequent TBLASTX analysis indicated that 49 probesets with the criteria outlined above represented genes that showed best BLAST hits to fungal sequences (Additional file 2). There were additional probes designed to ESTs that showed similarity to fungal sequences but the ESTs were short and the BLAST scores were unreliable, so they were excluded from further analysis. Of the 49 genes identified as putative fungal genes, 22 are represented by a single EST, and all are present exclusively in $M$. truncat$u l a / G$. intraradices mycorrhizal root cDNA libraries and are therefore likely to represent G. intraradices genes. Experimental analysis of ten genes confirmed that they are $G$. intraradices genes. They could be amplified by PCR from G. intraradices genomic DNA and not from M. truncatula genomic DNA (Table 1; Figure 1). Except for the putative G. intraradices a-tubulin a1 gene, which is highly conserved, the primers designed to the G. intraradices genes did not amplify transcripts from G. versiforme. It has been shown that despite a common genus name, these two fungi are only distantly related [67]. Eight of these genes (TC100037, TC103687, TC104499, TC105031, TC109807, TC111242, TC112506 and TC105246) were represented on the $16 \mathrm{~K}$ array although their origin was not demonstrated [39].

Previous estimates suggest that total RNA extracted from a highly colonized, whole root system contains not more than 12\% AM fungal RNA [68]. Consequently, it might be predicted that the fungal transcripts represented in the EST libraries and consequently represented on the GeneChip, are likely to represent the most highly expressed fungal genes. Interestingly, the fungal genes represented on the array include genes predicted to encode enzymes of $\mathrm{N}$ metabolism, specifically, the urea cycle (Additional file 2).

\section{Development of a laser microdissection procedure suitable for the capture of cortical cells from M. truncatula mycorrhizal roots}

To enable LM of cortical cells containing arbuscules, the first issue was to identify suitable regions of the root system to fix and embed. In an AM symbiosis, the fungus proliferates in the inner cortex of the root and in M. truncatula mycorrhizal roots, the colonized regions are not readily visible without fixing and staining. In particular, it is difficult to identify regions of the root with infections that contain large numbers of arbuscules. To facilitate this, our goal was to first develop a M. truncatula transgenic plant line in which the colonized regions of the root would be marked by expression of green fluorescent protein (GFP). Previously, we had identified MtSCP1, a gene that is expressed only in mycorrhizal roots, specifically in colonized regions of the roots [36]. Analysis of an MtSCP1 promoter-GFP fusion construct in M. truncatula transgenic roots indicated that the construct reported the presence of the AM fungus in the cortex [36]. The MtSCP1 promoterGFP fusion construct was transferred to Agrobacterium tumefaciens and M. truncatula transgenic plants were generated. The transgenic plants showed the same expression patterns as seen previously and strong GFP fluorescence reported the presence of the fungus in the cortex (Additional file 3). Using the transgenic plants, we were able to identify and dissect out highly colonized regions of the root. These were then used for LM experiments. In addition, RNA extracted from these intact colonized root pieces is highly enriched for plant and fungal transcripts associated with colonized regions of the root, and are useful RNA resource.

A review of LM and its use in plants, revealed that a wide variety of protocols have been used for the preparation of plant tissue for LM [52]. Each different plant tissue has unique characteristics and therefore it is necessary to determine empirically, the most appropriate fixation and embedding regime to retain satisfactory cellular morphology, while still enabling extraction of high RNA quality. We based our approach on a protocol developed by Kerk et al. [51] and then evaluated aspects of fixation, embed- 


TC105406
AM fungal $\alpha$-tubulin a1
TC85704
Glomus versiforme
ferritin-like heavy chain
TC112506
ADP-ribosylation factor
TC105524
Probable autophagy
protein AUT7
TC111688
Related to P24 protein
TC105246
Delta-9 fatty acid
desaturase
DQ063587.1
Glutamine synthetase*
TC105031
Arginase

TC105406
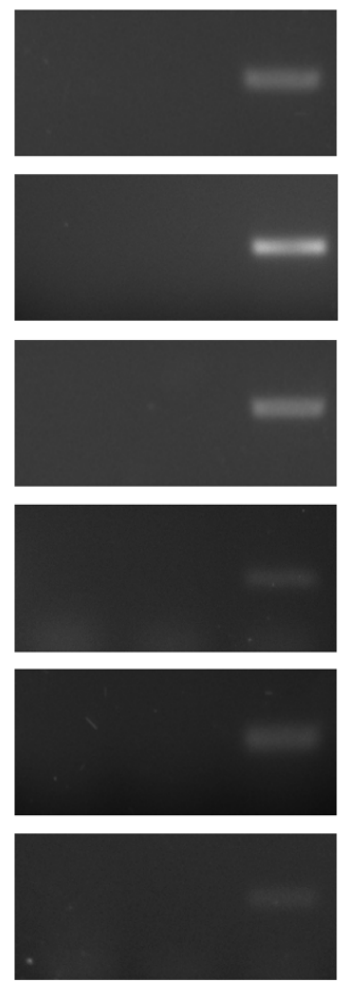

TC109807

Probable ornithine aminotransferase

AL387743
Arginino succinate
synthase

TC100037

Asparagine synthetase

TC106186

Probable acyl-CoA

dehydrogenase

\section{AL382096 \\ Phospholipid-transporting ATPase}

\section{AY116210 \\ MtPT4}

IMGAG|1723.m00046 Ammonium transporter
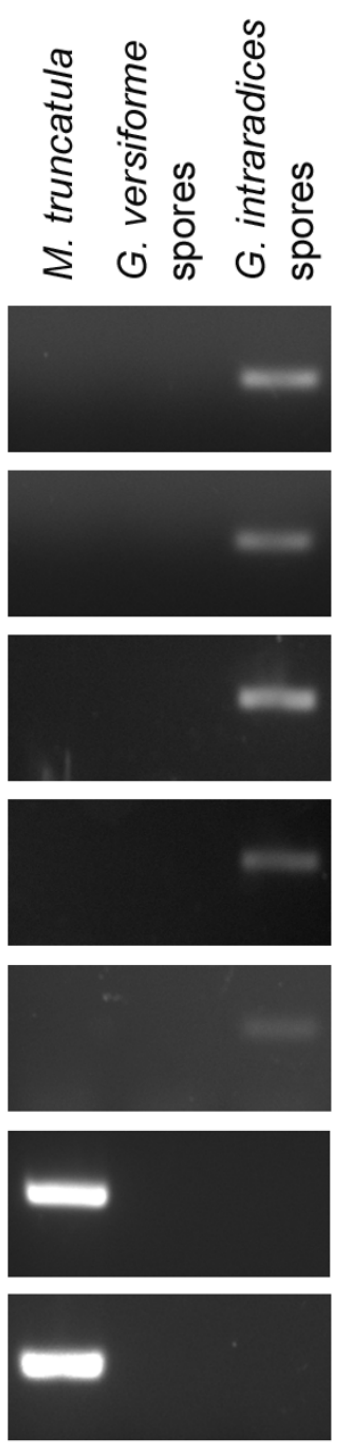

\section{Figure I}

Analysis of the origin of putative G. intraradices genes represented on the Medicago GeneChip ${ }^{\circledR}$. PCR amplification using DNA isolated from $M$. truncatula roots, $G$. versiforme spores or $G$. intraradices spores. MtPT4 and an ammonium transporter are positive controls for the M. truncatula. Primers designed to TCI05406, a putative $\alpha$-tubulin al gene amplify $\alpha$ tubulin from both $G$. intraradices and $G$. versiforme. TC85704 is a $G$. versiforme gene.

ding, RNA extraction and amplification to find conditions optimal for M. truncatula mycorrhizal roots. RNA quality was evaluated using a bioanalyzer and/or agarose gel electrophoresis. Tissues were fixed in Farmer's fixative and fixation times of 12 or $24 \mathrm{~h}$ yielded RNA with an RNA integrity number (RIN) of 8.5 (intact RNA, RIN $=10$ ) as assessed by a bioanalyzer. In addition, fixation at 12 and
24 hours yielded larger size amplified, antisense RNA (aRNA) molecules, than a $4 \mathrm{~h}$ fixation (data not shown). We experienced considerable difficulties with RNA degradation during the paraffin embedding and xylene de-waxing stages, so as an alternative to paraffin wax, we tested Steedman's wax, a polyester wax used for immunolocalization [69-71]. Steedman's wax has the advantages that it 
can be mixed under RNase-free conditions, has a lower melting temperature $\left(38-40^{\circ} \mathrm{C}\right)$, and sections can be dewaxed easily with ethanol. The RNA quality extracted from root samples embedded in Steedman's was good $($ RIN = 6.7) and the morphology of the sections were comparable to sections made from tissues embedded in paraffin wax (Figure 2).

LM and laser pressure catapulting was carried out with the P.A.L.M. microbeam system. Between 400 and 600 cortical cells were harvested directly into lysis buffer and RNA was isolated within 12 hours of harvest. Two rounds of linear RNA amplification yielded over $23 \mu \mathrm{g}$ of aRNA (Additional file 4). To validate the LM RNA, we examined the expression of MtPT4, a gene expressed exclusively in cells containing arbuscules. In addition, we assessed expression of $M t S C P 1$, and $M t B C P 1$, two genes expressed in this cell type that are suitable as additional markers. The latter two genes are not unique to colonized cortical cells $[28,36,38]$. MtPT4, MtSCP1, and MtBCP1 transcripts were detected in two biological replicate samples of RNA from cells with arbuscules and not from cortical cells captured from mock-inoculated roots. Elongation factor 1alpha $(E F 1 \alpha)$ transcripts were present in RNA samples from both cell types (Figure 3 ). The length of individual molecules present in the aRNA sample was evaluated by examining MtPT4 transcripts [28]. cDNA was synthesized using random priming and the length of molecules in the samples was evaluated by RT-PCR using primers distributed across the MtPT4 gene. Although we were unable to amplify the intact $1.8 \mathrm{~kb} \mathrm{MtPT4}$ transcript, primers sets that amplified less than $210 \mathrm{bp}$ fragments at the $5^{\prime}$ end, middle, or 3' end of the coding sequence showed that the aRNA represents complete transcripts but not necessarily as single intact molecules (Additional file 5).

\section{M. truncatula gene expression in cortical cells containing G. versiforme and $\mathbf{G}$. intraradices arbuscules}

Following development and validation of the LM method, we generated cell-type specific RNA samples from cortical cells of $M$. truncatula mock-inoculated roots, and cortical cells containing either G. versiforme or G. intraradices arbuscules. In addition, we prepared RNA from the highly-colonized 'mycorrhiza-enriched' root pieces from G. versiforme-colonized roots. Genes selected for expression analysis in these samples included 6 genes that were previously reported as mycorrhiza-induced, but whose spatial expression patterns were not known, and 12 novel genes that showed increased transcript levels in the GeneChip ${ }^{\varpi}$ experiment (Table 1). Initially, transcript levels were monitored in the RNA from the intact, enriched root piece samples. All 12 new genes showed an increase in transcript levels in the RNA from enriched mycorrhizal root samples relative to that of the mock-inoculated controls confirming the expression patterns observed on the array (Figure 4). This was observed for both M. truncatula roots colonized with $G$. versiforme and $G$. intraradices. Transcripts for 9 of these genes were extremely low or not detectable in mock-inoculated roots. In the RNA samples from laser microdissected cells, 13 of 18 genes assayed showed expression in cortical cells containing arbuscules and not in the cortical cells from mock-inoculated control roots (Figure 5). For 6 genes, transcripts were detected in only one of the G. versiforme arbuscule-cortical cell samples indicating some variability in the samples. However, analysis in G. intraradices arbuscule-cortical cell samples confirmed the expression in this cell-type (Figure 5). It is possible that sample variability arises from variation in the developmental stages of the arbuscules in the sample. This could lead to differences in the samples and would likely have the greatest effects on low abundance transcripts or on genes whose expression is associated with a specific phase of arbuscule development. Using this approach, transcripts of two putative transcription factors of the GRAS family, a peptide transporter, an ammonium transporter, three genes associated with lipid biosynthesis or degradation and a LysM-receptor like kinase were detected in cortical cells containing arbuscules and were not detected in cortical cells from the mock-inoculated controls. Four mycorrhiza-induced genes, the putative copper transport protein, dihydrodipicolinate synthase, inositol polyphosphate phosphatase and an SNF1-like kinase were not detected in cortical cells containing arbuscules. As transcripts of the latter 4 genes were detected in the colonized root pieces (Figure 4), it can be concluded that they are expressed in mycorrhizal roots but in a cell type other than the cortical cells containing arbuscules.

Analysis of $\mathbf{G}$. intraradices gene expression in arbuscules The expression of $10 \mathrm{G}$. intraradices genes identified on the arrays was evaluated in RNA from both the colonized root pieces and the LM cell-type specific samples (Table 1; Figure 6). The genes selected for analysis included those predicted to encode enzymes of $\mathrm{N}$ metabolism, in particular the urea cycle including a putative arginase gene. Consistent with the GeneChip results, transcripts for all 10 genes were present in $M$. truncatula/G. intraradices mycorrhizal roots samples. In addition, all genes tested showed expression in arbuscules. This suggests that the urea cycle is likely to be active in this tissue. Previous NMR studies had predicted this but a direct demonstration of the presence of transcripts in arbuscules had not been made. In addition to genes associated with $\mathrm{N}$ and amino acid metabolism, we also detected a putative G. intraradices AUT7 homolog and a putative phospholipids-transporting ATPase in arbuscules. AUT7 is part of the autophagic machinery and is considered a marker of cells undergoing an autophagic response. The presence of this transcript in arbuscules is the first molecular hint that arbuscule turnover might involve autophagy. The phospholipid-trans- 
A)

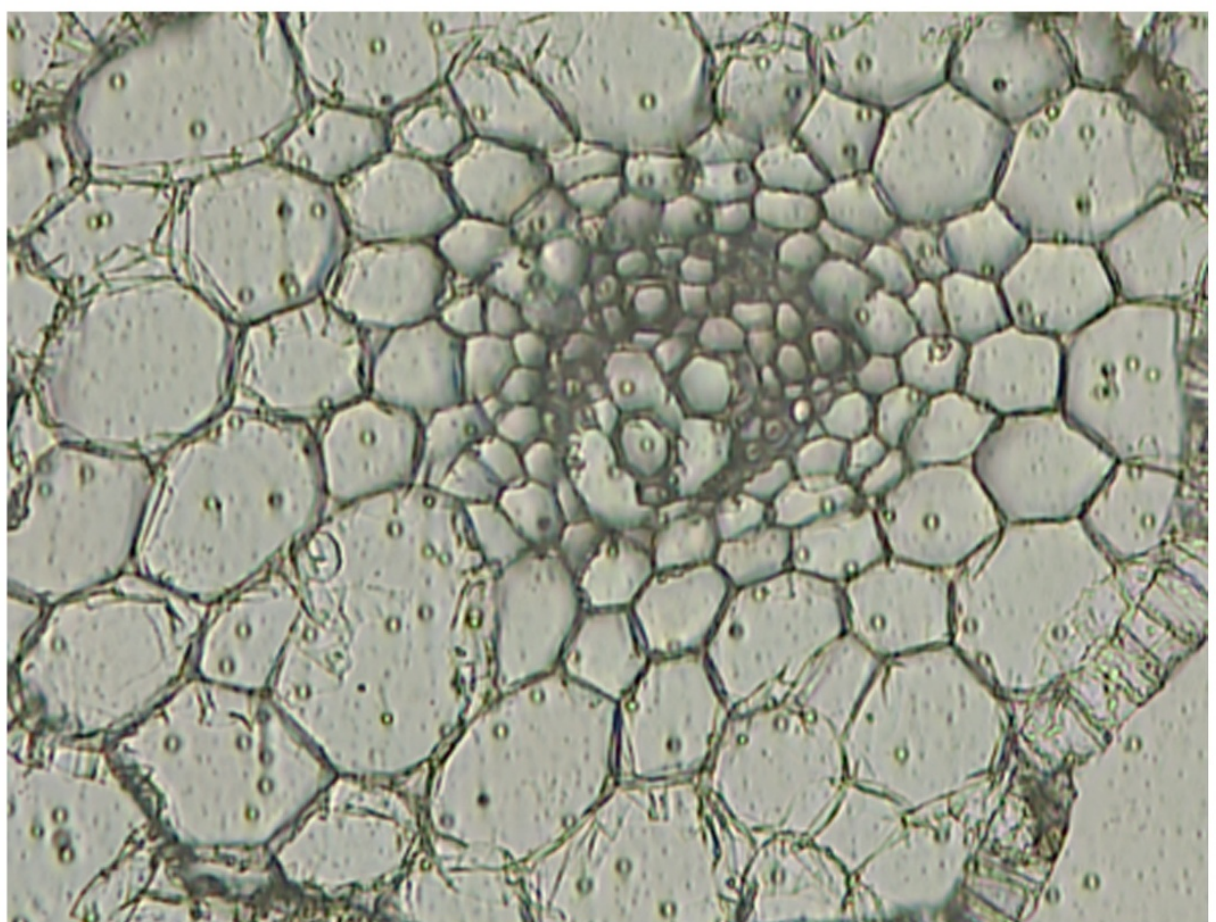

B)

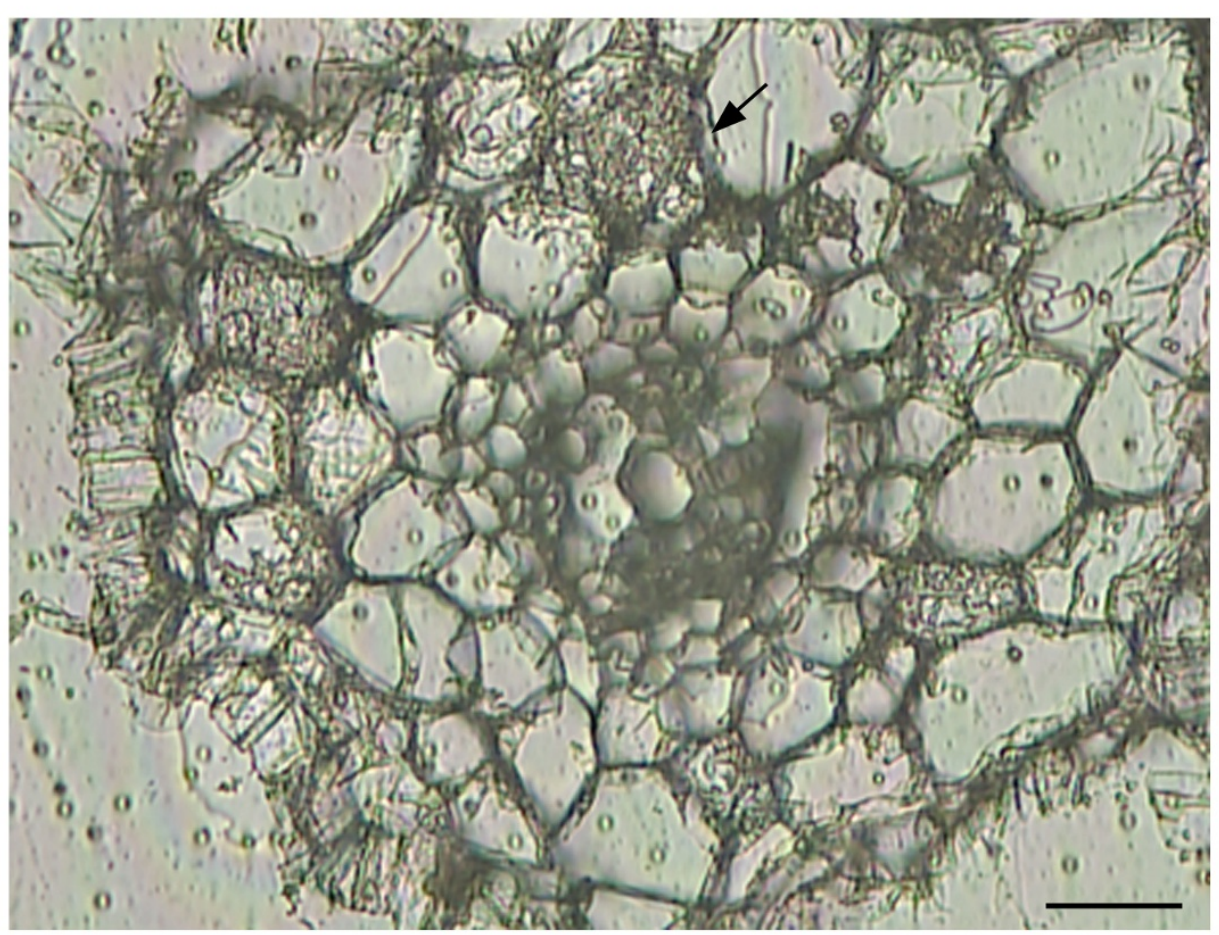

Figure 2

Transverse sections of $M$. truncatula roots used for laser microdissection. Mock-inoculated controls (A) and inoculated with $G$. versiforme (B). The arrow shows a cortical cell containing an arbuscule. Bar $=25 \mu \mathrm{m}$ 


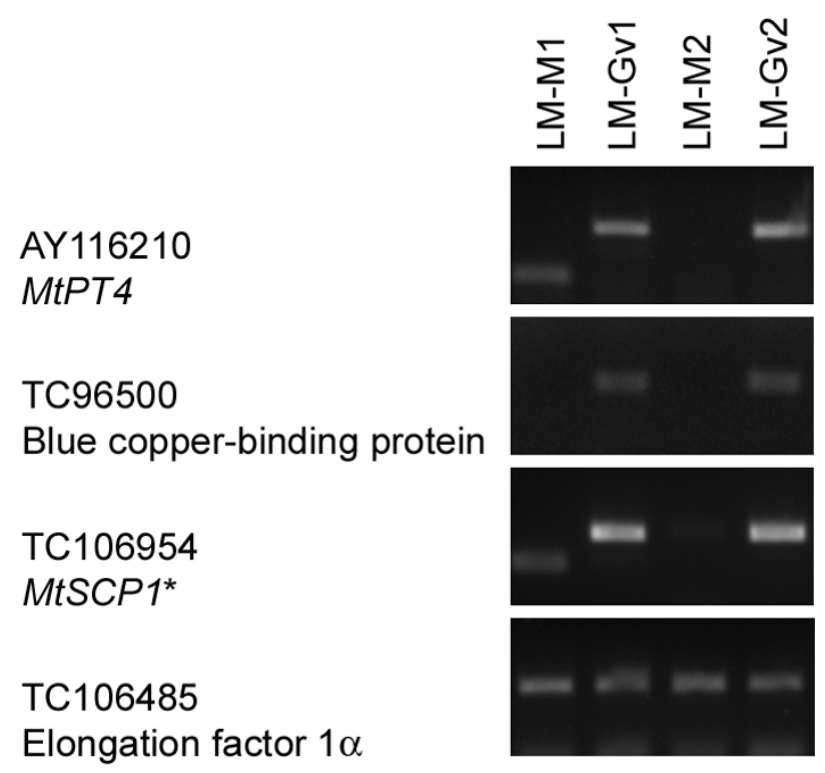

Figure 3

RT-PCR analysis to detect transcripts of MtPT4, MtBCPI and MtSCPI in colonized cortical cells. RNA from cortical cells from two independent mock-inoculated M. truncatula root systems (LM-MI and LM-M2) and cortical cells containing arbuscules from $M$. truncatula/G. versiforme mycorrhizal root systems (LM-Gvl and LM-Gv2) was used. Cortical cells were obtained by laser microdissection (LM). *Two rounds of PCR were carried out for TCI06954. A M. truncatula elongation factor I $\alpha$ (TC 106485) was included as endogenous control.

porting ATPases are P-type ATPases whose activity is required to maintain phospholipid asymmetry in the membrane bilayers [72]. In Magnaporthe grisea, the activity of a phospholipid-transporting ATPase was required for development of the penetration hypha and further growth of the fungus within the plant cells [73].

\section{Discussion}

Here, we used the Medicago GeneChip ${ }^{\circledR}$ to extend the transcript dataset for mycorrhizal roots and coupled this with LM and RT-PCR to assess gene expression specifically at the cortical cell-arbuscule interface. At the time that this work was initiated, there were only a few reports of LM of root cells or roots associated with other organisms, consequently, it was necessary to test and modify existing protocols to develop a protocol suitable for $M$. truncatula mycorrhizal roots. The protocol developed was based largely on Kerk et al. [51] and the main modification was the nature of the embedding material. Following initial difficulties with the quality of the RNA extracted from paraffin-embedded tissues, we tested Steedman's wax with the idea that RNA degradation would be minimized by exposing roots to lower temperatures during embedding, and the use of ethanol for de-waxing would be less detrimental than xylene. This proved to be the case and this low-melting-temperature, ethanol-soluble wax enabled us to extract RNA from $M$. truncatula roots of superior quality. LM of approximately $400 \mathrm{M}$. truncatula root cortical cells, followed by two rounds of linear RNA amplification provided microgram quantities of RNA for RT-PCR analyses. These cell-type specific RNA samples were validated by monitoring the expression of three genes, MtPT4, $M t S C P 1$ and MtBCP1, whose expression patterns have been described previously [28,36,38]. Recently, Balestrini et al. [59] reported the use of methacarn fixation and paraffin embedding for LM of cells from tomato roots colonized by the AM fungus $G$. mosseae. However, they did not couple this with linear RNA amplification and consequently, it was necessary to harvest a large quantity of cells, between 3,000 and 11,000 cells to obtain nanogram quantities of RNA. Although the linear RNA amplification used in our approach may lead to a 3' end bias in the transcript molecules, comparative analyses are possible with careful primer design.

The GeneChip analysis provided a greatly expanded view of genes induced in the AM symbiosis, including several transcription factors and receptors. As reported previously, development of the AM symbiosis is accompanied by significant alterations in gene expression including the expression of novel 'mycorrhiza-specific' genes. Surprisingly, transcription factors responsible for mycorrhizaregulated gene expression are entirely unknown. Here we identified 5 members of the GRAS transcription factor family induced in mycorrhizal roots (AL386879, AL386880, TC105118, IMGAG|1755.m00026, and AJ499899). The GRAS family of proteins is unique to plants and its name derives from three members that were initially identified $\underline{G A I}, \underline{R G} \underline{A}$, and $\underline{S} C R$ [74-76]. The Arabidopsis GRAS family contains at least 33 members including Scarecrow and Short Root, two proteins that play a central role in root development (reviewed by [77]. Two M. truncatula GRAS proteins, MtNSP1 and MtNSP2, are essential for the activation of Nod-factor-induced genes in the rhizobial symbiosis $[62,63]$. Given their roles in root development and symbiosis, members of this family are likely candidates for regulating gene expression in mycorrhizal roots. Here, we confirmed by RT-PCR that two putative GRAS genes; AJ499899 and AL386880, were expressed in G. versiforme- or G. intraradices-colonized roots, with non-detectable or low levels of transcripts in mock-inoculated roots. Furthermore, AJ499899 and AL386880 transcripts were not detected in cortical cells from mock-inoculated roots but were detected in arbuscule-containing cortical cells. Consequently, it is possible that these GRAS factors regulate gene expression in colonized cortical cells. The current data do not preclude a role 
IMGAG|1723.m00046 Ammonium transporter

TC108660

GDSL-motif lipase

TC99271

Palmitoyl-acyl carrier protein thioesterase

IMGAG|1197.m00015 MtLYR1

AL386880

GRAS family member

TC110731

Triacylglycerol/steryl ester lipase-like protein

AY116210

MtPT4

\section{TC106485}

Elongation factor $1 \alpha$
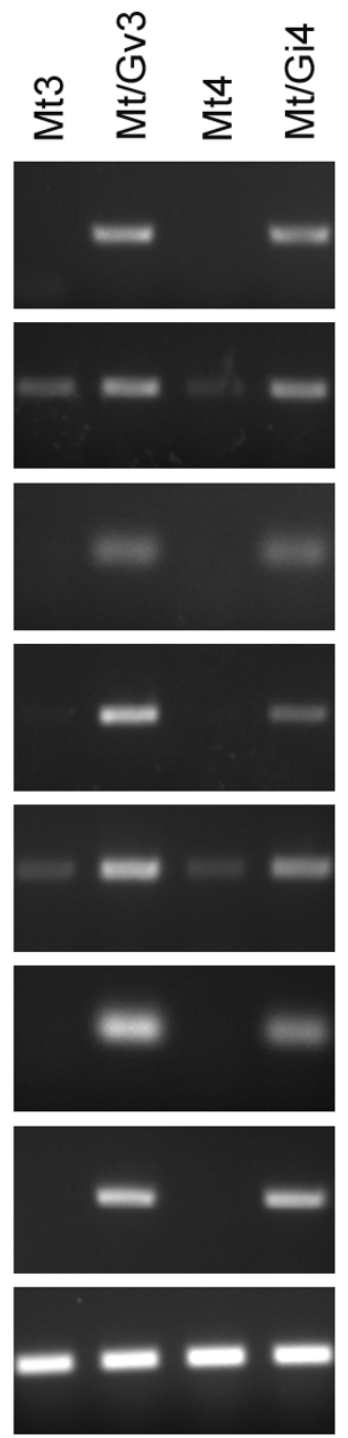

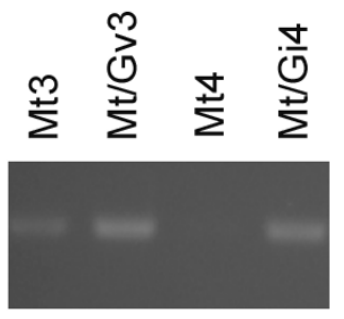

AJ499899
GRAS family member

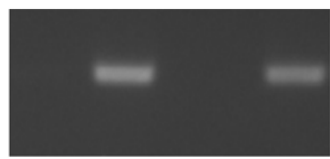

TC97522

Copper transport protein

TC104979

Dihydrodipicolinate synthase*

IMGAG|906.m00010 Inositol polyphosphate phosphatase

AL387494

Peptide transporter 2

AW573798

SNF1-related kinase
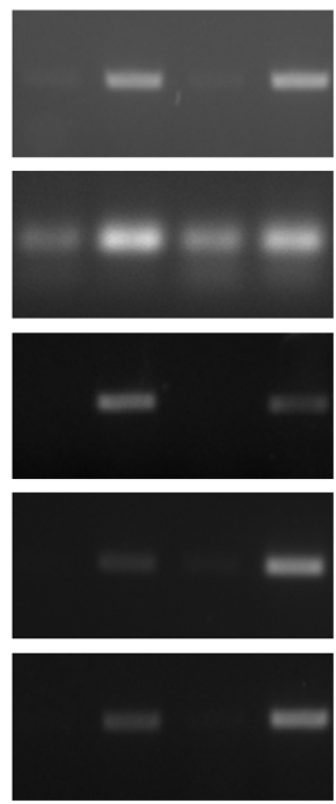

\section{Figure 4}

RT-PCR analysis to detect transcripts of thirteen $M$. truncatula genes using RNA from mock-inoculated roots, and from mycorrhizal roots. RNA from root pieces from $M$. truncatula mock-inoculated roots (Mt3) or $M$. truncatula/G. versiforme mycorrhizal roots (Mt/Gv3), and from $M$. truncatula mock-inoculated roots (Mt4) or $M$. truncatula/G. intraradices mycorrhizal roots $(\mathrm{Mt} / \mathrm{Gi} 4)$ was used. The $M$. truncatula transgenic plant line $\mathrm{pMtSCPI::GFP}$ was used and sampling of colonized root pieces was guided by the expression of GFP. Genes selected for analysis were up-regulated $\geq 2$-fold in the Medicago GeneChip ${ }^{\circledR}$ experiment. *TCl04979 was reported previously as mycorrhiza-induced. MtPT4 was used as positive control and elongation factor I $\alpha$ (TCI06485) was included as endogenous control.

in other cell types and one GRAS factor, represented by EST AL386880 is also highly expressed in root nodules. It would be interesting to know whether expression is associated with cells containing symbiosomes [60].

In addition to transcription factors, receptor proteins operating in signaling pathways, involved in arbuscule development are also entirely unknown. In contrast, receptors involved in signaling during nodule development have been described. Genes predicted to encode LysM-RLK including NFR1 and NFR5 in Lotus japonicus $[78,79]$ and orthologs LYK3 and NFP in M. truncatula [80], and SYM10 in pea [78] are involved in Nod factor signaling and are likely to be Nod factor receptors. The $M$. truncatula LysM-RLK family contains at least 17 genes, which, based on their kinase domain phylogeny, are 


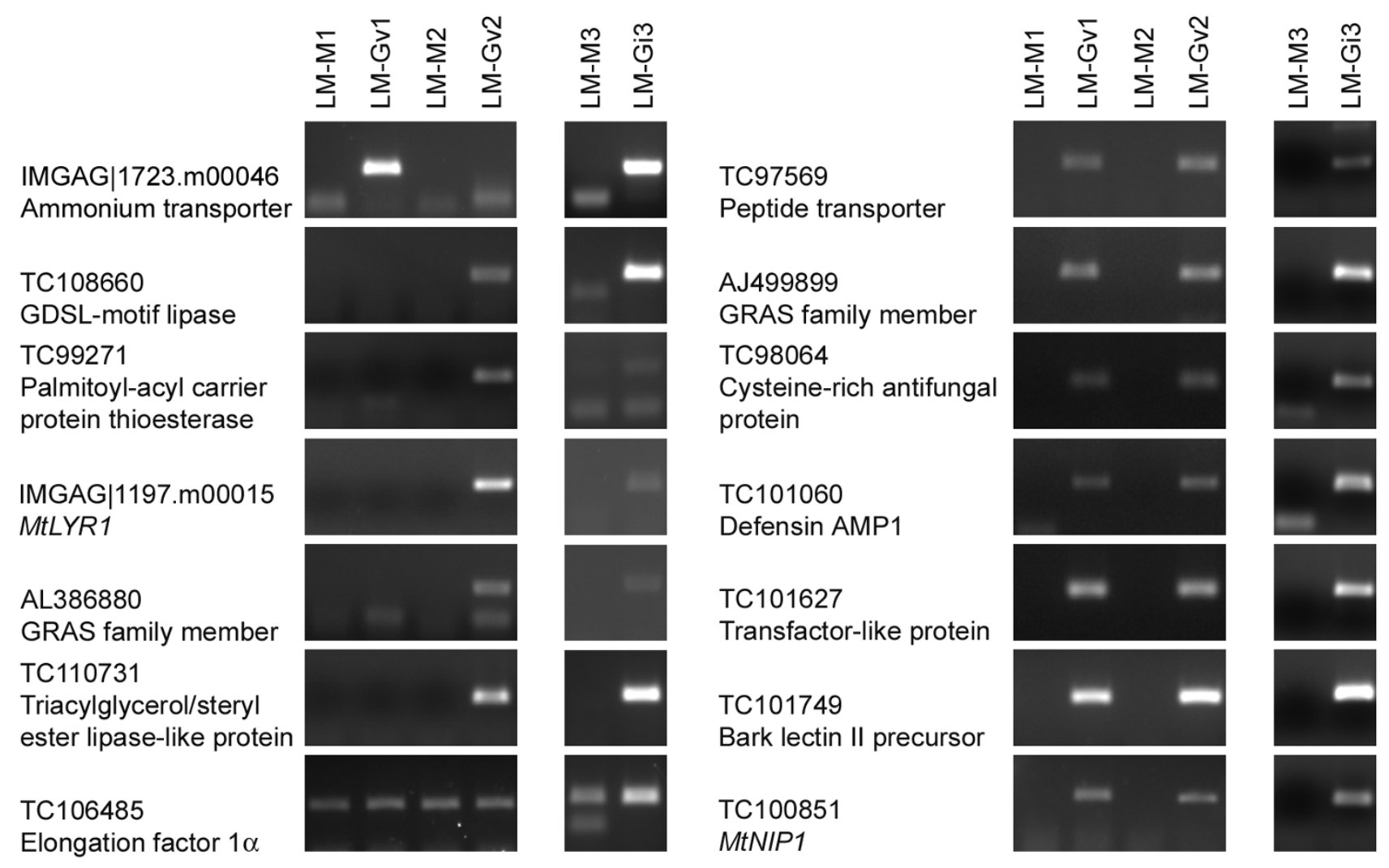

\section{Figure 5}

RT-PCR to detect transcripts of thirteen novel mycorrhiza-induced $M$. truncatula genes in colonized cortical cells. RNA from cortical cells from three independent mock-inoculated $M$. truncatula root systems (LM-MI, LM-M2 and LMM3) and cortical cells containing arbuscules from $M$. truncatula/G. versiforme mycorrhizal root systems (LM-Gvl and LM-Gv2) or M. truncatula/G. intraradices (LM-Gi3) mycorrhizal root systems was used. Cortical cells were obtained by laser microdissection (LM). Transcripts that were induced in only one of the $M$. truncatula/G. versiforme $L M$ samples were further evaluated in $M$. truncatula/G. intraradices LM samples. The larger size fragment in LM-Gi3 (TC97569) may indicate presence of another peptide transporter gene. TCI06485 was used as endogenous control.

divided into three subfamilies. Subfamily II contains NFP and four other members of the family of which MtLYR1 is most similar in sequence to NFP. There are no ESTs for MtLYR1 and in previous studies, transcripts were detected in nodulated roots but not in nodules [65]. Here, we found that MtLYR1 (IMGAG|1197.m00015) transcripts increased in $G$. versiforme or $G$. intraradices-colonized roots. Moreover, the MtLYR1 gene was detected in cortical cells with arbuscules. Like NFP, MtLYR1 has three LysM domains and a Ser-Thr kinase domain that lacks the activation and P-loops and consequently, it probably lacks kinase activity [65]. It is possible that these 'inactive' kinases dimerize with an active receptor kinase to form a receptor with kinase activity and consistent with this, heterodimerization of NFR1 and NFR5 has been demonstrated. LysM domains recognize $\mathrm{N}$-acetyl glucosamine or structurally similar molecules such as Nod factors [81-83]. It is possible that the LysM domain of MtLYR1 recognizes the $\mathrm{N}$-acetyl glucosamine residues in chitin in the AM fungal cell walls and given its expression pattern, it could play a role in signaling during arbuscule development.

Cell biological analyses of the arbuscule-cortical cell interface suggest that the peri-arbuscular membrane increases the membrane area within the cortical cell at least 10 -fold. Consistent with this, metabolite profiles of mycorrhizal roots indicate a significant increase in fatty acids [84]. The GeneChip analyses identified two new mycorrhizainduced genes predicted to be involved in fatty acid metabolism; a putative palmitoyl-ACP thioesterase gene (TC99271) and a triacylglycerol/steryl ester lipase-like protein gene (TC110731) that show a 49- and 102-fold increase in transcript levels respectively. RT-PCR analysis indicated that TC99271 and TC110731 transcript levels increase in cortical cells with arbuscules. Fatty acid synthesis in plants is a cyclic process and the extension cycles 
TC105406

AM fungal $\alpha$-tubulin a1

TC112506

ADP-ribosylation factor

TC105524

Probable autophagy

protein AUT7

TC111688

Related to P24 protein

TC105246

Delta-9 fatty acid

desaturase

DQ063587.1

Glutamine synthetase*

A)
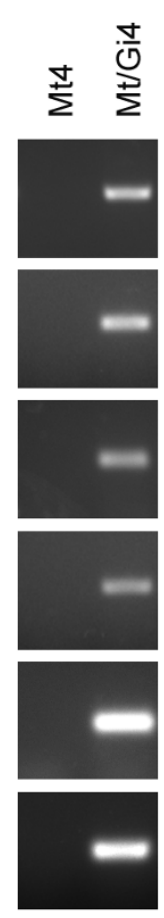

TC105031

Arginase

TC109807

Probable ornithine aminotransferase

AL387743

Arginino succinate synthase

TC100037

Asparagine synthetase

TC106186

Probable acyl-CoA dehydrogenase

AL382096

Phospholipid-transporting ATPase
B)

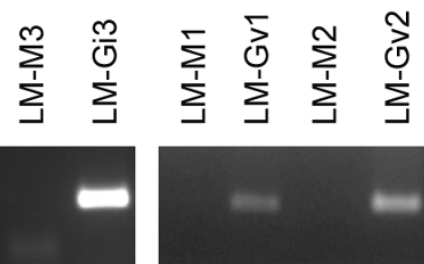

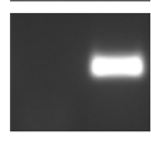
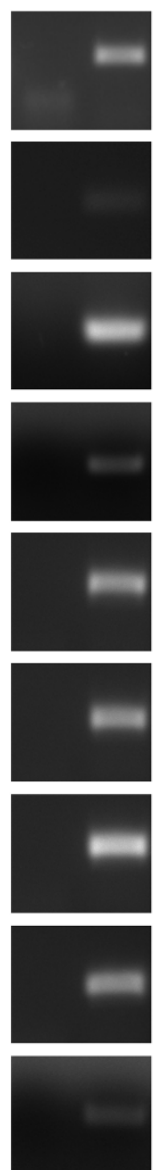

\section{Figure 6}

RT-PCR analysis to detect transcripts of $G$. intraradices genes in mycorrhizal roots and in arbuscules. Panel A: RNA from whole roots systems of $M$. truncatula mock-inoculated roots (Mt4) and $M$. truncatula/G. intraradices mycorrhizal roots (Mt/Gi4). The M. truncatula transgenic plant line PMtSCPI::GFP was used and sampling of colonized root pieces was guided by the expression of GFP. Panel B: RNA from LM cortical cells from M. truncatula mock-inoculated roots (LM-MI, LMM2 and LM-M3) or cortical cells containing arbuscules from M. truncatula/G. intraradices mycorrhizal roots (LM-Gi3) or M. truncatula/G. versiforme mycorrhizal roots (LM-GvI and LM-Gv2). Primers designed to TC105406, a putative $G$. intraradices $\alpha$-tubulin al gene amplify $\alpha$-tubulin from both $G$. intraradices and $G$. versiforme. This was included as positive control in all samples.G. intraradices glutamine synthetase was included as an additional positive control. 
involves the binding of acyl chains to a soluble acyl carrier protein (ACP), and specific thioesterases hydrolyze the newly formed acyl-ACP into fatty acids and ACP [85]. An increase in palmitoyl-ACP thioesterase gene expression suggests an increase in the biosynthesis of palmitic acid. Consistent with this, a recent metabolite profile of $G$. intraradices/M. truncatula roots showed that mycorrhizal roots contained high levels of palmitic and oleic acids during active phases of AM symbiosis [84]. Oleic acid $\left(18: 1 \Delta^{9}\right)$ is created by a desaturation reaction catalyzed by a delta-9 desaturase. Surprisingly, a G. intraradices delta-9 desaturase gene was expressed highly in mycorrhizal roots and specifically in cells with arbuscules. Previous studies had speculated that the fungus might obtain palmitic acid from the plant, and even suggested that AM fungi might lack fatty acid synthase activity and thus be dependent on host lipid [86]. In the absence of a full genome sequence, it is not possible to determine whether this is correct, however, our findings of complementary gene expression patterns in the two symbionts is intriguing.

Other metabolic changes documented in mycorrhizal roots include an increase in amino acids [84]. In plants, there are at least three protein families involved in transport of small peptides, the $\mathrm{ABC}$ transporters, the di/tripeptide transporters (PTR family) and the oligopeptide (OPT) family. Two genes (AL387494 and TC97569) of the PTR family were expressed in mycorrhizal roots and TC97569 was detected in cells containing arbuscules. The GeneChip experiment also led to the identification of other new genes predicted to encode transport proteins including a copper transport protein (TC97522) and an ammonium transporter (IMGAG|1723.m00046) and the latter was expressed in cells with arbuscules. The identification of a mycorrhiza-induced ammonium transporter is particularly interesting. It is clear from many studies that in addition to $\mathrm{Pi}, \mathrm{N}$ is also transferred from the fungus to the plant and recent analyses indicate that $\mathrm{N}$ is likely transferred to the plant as ammonium. This ammonium transporter is a strong candidate for a role in the acquisition of ammonium delivered via the fungus. Metabolic labeling studies and gene expression analyses led to a model in which inorganic $\mathrm{N}$ taken up by the fungal extra-radical mycelium is converted into arginine which is transported into the intra-radical mycelium, where it is broken down into amino acids. Ammonium, resulting from arginine breakdown is proposed to be exported to the plant [29]. In further support of the labeling studies, Govindarajulu et al. [29] showed elevated transcripts of G. intraradices ornithine aminotransferase, a urease accessory protein and an ammonium transporter in the intra-radical mycelium relative to the extra-radical mycelium.

Interestingly, the G. intraradices genes present on the $M$. truncatula array include genes predicted to encode enzymes of the urea cycle as well as amino acid metabolism. RT-PCR analysis showed that these genes were expressed in G. intraradices-mycorrhizal roots, and analysis of the cell-type specific samples, indicates that they are expressed in the arbuscules. These data extend the previous findings, showing that the genes of urea and amino acid metabolism are expressed in the arbuscules. In addition, our data set includes a gene predicted to encode arginase that breaks down arginine to release ornithine and urea. This is a key step for the release of ammonia and further supports the model proposed by Govindarajulu et al. [29]. In addition to the urea cycle, we detected G. intraradices asparagine synthetase and glutamine synthetase gene expression in arbuscules. This suggests that ornithine, released via arginase activity, may be cycled into asparagine and glutamine through the action of asparagine synthetase and glutamine synthetase. Interestingly, the metabolite profiling studies found higher levels of specific amino acids, including Glu, Asp, and Asn in mycorrhizal roots [84]. From these studies, it is not possible to determine whether the amino acids are in the plant or AM fungus, however, coupled with the gene expression studies, there is evidence to suggest that at least some of this amino acid accumulation may result from activities in the fungus.

\section{Conclusion}

Using a combination of arrays, LM and RT-PCR, we have extended the $M$. truncatula/G. intraradices mycorrhizal root transcriptome and identified novel $M$. truncatula and G. intraradices genes that are expressed in cortical cells harboring arbuscules. By virtue of their expression patterns, the genes expressed in this cell type are candidates for mediating aspects of development or function of the symbiotic arbuscule-cortical cell interface. Novel genes potentially involved in signaling and in $\mathrm{N}$ transport and metabolism are of particular interest. This dataset will be valuable for future studies aimed at determining the molecular events that control arbuscule development, and $\mathrm{N}$ transport and metabolism in the AM symbiosis.

\section{Methods \\ Plant transformation}

The pMtSCP1::GFP construct described in Liu et al. [36] was introduced into Agrobacterium tumefaciens (LBA4404) and was used to transform Medicago truncatula cv. Jemalong, (A17) according to Trieu and Harrison [87] with minor modifications as described in Javot and Harrison [88]. Regenerated plants were selected with $1 \mathrm{mg} \mathrm{L}^{-1}$ bialaphos and were allowed to self pollinate. The progeny were tested to verify the presence of the GFP and Bar genes, and were inoculated with G. versiforme to verify the mycorrhiza-inducible expression of sGFP [36]. Seed from one transgenic line MtSCP-GFP1-1 (from the T3 or T4 generations) were used in the LM experiments. 


\section{Plant material, growth conditions and inoculation methods}

Plants were grown in a growth room under a $16 \mathrm{~h}$ light $\left(25^{\circ} \mathrm{C}\right)$ and $8 \mathrm{~h}$ dark $\left(22^{\circ} \mathrm{C}\right)$ period. G. intraradices was maintained in cultured carrot roots on plates, and spores were prepared from the plates as described [89]. Stock cultures of $G$. versiforme was maintained on leek plants or Bahia grass in pot culture and the preparation of surfacesterilized spores has been described previously $[36,90,91]$. Plants were supplied with half-strength Hoagland's solution containing $20 \mu \mathrm{M}$ potassium phosphate twice a week.

For the GeneChip experiment, the root tissue was from the same experiment as that described in Liu et al. [39]. Briefly, 14 day old M. truncatula (A17) plants were inoculated with 8,000 G. intraradices spores/pot and grown for 30 days. Roots were harvested and frozen in liquid nitrogen. Random samples were collected for the assessment of their colonization levels with the gridline intersect method [92]. The colonization levels of the three G. intraradices inoculated replicates used in the array experiment were 49, 50 and 53\% root length colonized (RLC) as reported in Liu et al. [39]. For all other experiments, the M. truncatula transgenic line $p M t S C P 1:: \mathrm{GFP}\left(\mathrm{T}_{3}\right.$ or $\mathrm{T}_{4}$ generation) was used.

To obtain highly colonized root pieces, 26 day old pMtSCP1::GFP M. truncatula plants were transplanted in large cones $(4 \times 20 \mathrm{~cm}$ : 1 plant per cone $)$ and were inoculated with 800 G. versiforme spores per plant or mockinoculated with the last rinse from the spore surface sterilization procedure as described previously [36,90,91]. At 28 days post-inoculation, roots were examined under a stereomicroscope equipped with UV-light, and regions of the root system that showed green fluorescence (Additional file 3 ) were dissected out and immediately frozen in liquid nitrogen, and stored at $-80^{\circ} \mathrm{C}$ for RNA isolation. Likewise, mock-inoculated pieces of roots were harvested in a similar manner from similar regions of the mockinoculated root systems.

For the LM experiments, 15 day old or 23 day old pMtSCP1::GFP M. truncatula plants were transplanted in large cones and inoculated with 1000 G. versiforme spores per plant or $1000 \mathrm{G}$. intraradices spores per plant, or mockinoculated as described previously. Plants were harvested at 22 or 26 days post-inoculation with G. versiforme or G. intraradices, respectively. The harvest of root sections took place during the evening hours to facilitate the tissue preparation for LM.

\section{Tissue preparation and laser microdissection}

The method described was based on that of Kerk et al. [51] with modifications. Instead of paraffin wax, the low melt- ing temperature Steedman's wax was used for embedding root tissues. Steedman's wax was prepared by melting 900 g polyethylene glycol 400 distearate (Sigma-Aldrich, St. Louis, MO) and $100 \mathrm{~g}$ 1-hexadecanol (Sigma-Aldrich) at $65^{\circ} \mathrm{C}$, and it was mixed thoroughly with a stirring bar. The wax was stored in 50-ml sterile tubes and only the volume needed was melted at $38^{\circ} \mathrm{C}$.

M. truncatula SCP1::GFP root systems were submerged in DEPC-treated autoclaved water and colonized regions were selected based on expression of GFP as described above. Mock-inoculated root pieces were collected in a similar manner. Root pieces of between 4 and $8 \mathrm{~mm}$ long were dissected and immediately transferred into 20-ml RNase-free scintillation vials containing freshly prepared Farmer's fixative (3:1 (v/v), ethanol: acetic acid). Roots were incubated in the fixative for $12 \mathrm{~h}$ with rotation at $4^{\circ} \mathrm{C}$, followed by dehydration also at $4^{\circ} \mathrm{C}$, in the following ethanol series: $75 \%(\mathrm{v} / \mathrm{v}), 85 \%, 95 \%$ (with $0.1 \%$ eosin y), $100 \%$ and $100 \%$ with transfer every $2 \mathrm{~h}$. The quality of RNA extracted from tissues in one block was evaluated by the bioanalyzer $(\mathrm{RIN}=6.7)$.

After the last ethanol step, half of the ethanol was removed and the vials were incubated at $38^{\circ} \mathrm{C}$ for $10 \mathrm{~min}$ prior to adding the molten Steedman's wax. Vials with $1: 1$ ethanol: wax, were incubated for $12 \mathrm{~h}$ at $38^{\circ} \mathrm{C}$, and followed by 3 changes of $100 \%$ wax at $2 \mathrm{~h}$ intervals. Roots were embedded in paper boats at room temperature. Blocks were stored in plastic bags until they were processed.

Sectioning with Steedman's wax was performed at cool room temperature (less than $23^{\circ} \mathrm{C}$ ). Transverse root sections of 10-15 $\mu \mathrm{m}$ were made using a Leica RM 2235 rotary microtome (Leica Microsystems Inc., Bannockburn, IL). Ribbons were arranged on UV-treated, $1 \mathrm{~mm}$ PENmembrane covered slides (P.A.L.M. Microlaser Technologies, Bernried, Germany) and they were stretched with a few drops of DEPC-treated autoclaved water. Slides were kept in a slide warmer at $32^{\circ} \mathrm{C}$ overnight. Sections were de-waxed by pipetting 100\% ethanol with a transfer pipette several times until the wax was not visible anymore, and then dried at $32^{\circ} \mathrm{C}$ before the cell harvest.

The P.A.L.M. Microbeam system with a Robomover (P.A.L.M. Microlaser Technologies) was used for LM. Cortical cells that contained arbuscules or cortical cells from mock-inoculated roots were counted and marked (Additional files 3,6). The contour of a cell or group of cells was cut twice with the laser and target cells were automatically catapulted into the cap of a microcentrifuge tube that contained RLT buffer (Qiagen Inc., Valencia, CA) with $\beta$-mercaptoethanol. We harvested cortical cells containing $G$. versiforme arbuscules or mock-inoculated controls from 2 
biological replicates (each plant was a replicate). For $G$. intraradices, cells from 3 plants were pooled as shown in the Additional file 4 . Cells were stored at $-80^{\circ} \mathrm{C}$ until RNA isolation.

\section{RNA isolation}

For the GeneChip Medicago genome arrays, root tissue from 3 biological replicates (G. intraradices- or mock-inoculated plants) were ground in liquid nitrogen using a mortar and pestle. Total RNA was extracted with Trizol reagent (Invitrogen Corporation, Carlsbad, CA) with additional phenol ( $\mathrm{pH}$ 6.6): chloroform $(1: 1, \mathrm{v} / \mathrm{v})$ and chloroform purification steps. RNA was treated with Turbo DNase I (Ambion Inc., Austin, TX), and column purified with an RNeasy MinElute CleanUp kit (Qiagen). RNA was quantified using a Nanodrop Spectrophotometer ND-100 (NanoDrop Technologies, Willington, DE) and evaluated for purity with the bioanalyzer.

For the small dissected root samples, root pieces harvested from 3 plants (G. versiforme- or mock-inoculated) were pooled and ground with a disposable pellet pestle in a centrifuge tube containing liquid nitrogen. Total RNA from root sections or LM cortical cells was isolated with the RNeasy Micro kit (Qiagen) according to the manufacturer's protocol.

\section{RNA amplification}

Five hundred nanograms of total RNA isolated from the dissected root pieces were amplified using the TargetAmp 1-round aRNA amplification kit (Epicentre Biotechnologies, Madison, WI). $3 \mu \mathrm{g}$ of aRNA or total RNA [G. versiforme- or mock-inoculated aRNA, and G. intraradices- or mock-inoculated RNA] were then treated twice with 1 Unit of Turbo DNase (Ambion Inc., Austin, TX). After an incubation of $20 \mathrm{~min}$ at $37^{\circ} \mathrm{C}$ each time, samples were purified using phenol (pH6.6): chloroform (1:1, v/v) and chloroform, followed by isopropanol precipitation.

Total RNA from LM cortical cells was amplified using the TargetAmp 2-round aRNA amplification kit (Epicentre Biotechnologies) and the aRNA yields are listed in Additional file 4 .

\section{Oligonucleotide design}

Primers were designed using Primer3 software [93] and the product sizes were less than $180 \mathrm{bp}$. To avoid non-specific product formation, oligonucleotides were designed with reduced self and cross dimer $\Delta G$ using NetPrimer software (PREMIER Biosoft International, Palo Alto, CA). Most primers were designed near the 3 ' end of the coding sequences or 3' UTR. All the primers that were used are listed in Additional file 7. Primers designed to detect a $G$. versiforme ferritin-like gene were based on the sequence in Additional file 8 .

\section{cDNA synthesis and PCR conditions}

First-strand cDNA was synthesized from $1.5 \mu \mathrm{g}$ of DNasetreated total RNA using SuperScript III (Invitrogen) with $500 \mathrm{ng}$ anchored oligo (dT) primers in a $20 \mu \mathrm{l}$ reaction. For the aRNA, $600 \mathrm{ng}$ of DNase-treated aRNA (1-round) was reverse-transcribed using $500 \mathrm{ng}$ random hexamers in a $40 \mu \mathrm{l}$ reaction. This reaction was incubated at room temperature for $5 \mathrm{~min}$ prior to $2 \mathrm{~h}$ cDNA synthesis at $50^{\circ} \mathrm{C}$ and $15 \mathrm{~min}$ at $70^{\circ} \mathrm{C}$. Following cDNA synthesis, either $110 \mu \mathrm{l}$ or $35 \mu \mathrm{l}$ of water were added to cDNA samples derived from $600 \mathrm{ng}$ aRNA or $1.5 \mu \mathrm{g}$ total RNA, respectively. Each PCR reaction consisted of $1 \mu \mathrm{l}$ cDNA in a 20 $\mu \mathrm{l}$ reaction with the following components: $4 \mu \mathrm{l} 5 \times$ GoTaq green reaction buffer, $0.4 \mu \mathrm{l} 10 \mathrm{mM}$ dNTP mix, $0.4 \mu \mathrm{l}$ each primer $(10 \mu \mathrm{M}), 0.5$ Units of GoTaq DNA polymerase (Promega Corporation, Madison, WI). The thermal profile consisted of incubation at $94^{\circ} \mathrm{C}$ for $1 \mathrm{~min}$, followed by 30 cycles at $94^{\circ} \mathrm{C}$ for $45 \mathrm{sec}$, maximum annealing temperature (see Additional file 7) for $45 \mathrm{sec}, 72^{\circ} \mathrm{C}$ for $45 \mathrm{sec}$, and a final incubation at $72^{\circ} \mathrm{C}$ for $5 \mathrm{~min}$.

For RT-PCR of the LM aRNA samples, the cDNA was generated using gene-specific primers. Seventy five ng of aRNA was mixed with $1 \mu \mathrm{l} 10 \mathrm{mM}$ dNTP mix and $0.25 \mu \mathrm{l}$ of gene-specific forward primer $(10 \mu \mathrm{M})$, and incubated at $65^{\circ} \mathrm{C}$ for $5 \mathrm{~min} .4 \mu \mathrm{l}$ of $5 \times$ first-strand buffer, $1 \mu \mathrm{l} 0.1 \mathrm{M}$ DTT, 10 Units of RNase OUT, 5 Units of SuperScript III reverse transcriptase and DEPC-treated autoclaved water up to $20 \mu \mathrm{l}$ were added. cDNA synthesis was performed at $50^{\circ} \mathrm{C}$ for $2 \mathrm{~h}$, followed by inactivation at $70^{\circ} \mathrm{C}$ for $15 \mathrm{~min}$. Each $20 \mu \mathrm{l}$ PCR reaction included $5 \mu \mathrm{l}$ of cDNA, $2 \mu \mathrm{l} 10 \times$ PCR buffer, $0.4 \mu \mathrm{l} 10 \mathrm{mM}$ dNTP mix, $0.4 \mu \mathrm{l}$ each primer $(10 \mu \mathrm{M}), 0.5$ Units of HotStarTaq DNA polymerase (Qiagen) and autoclaved water. In order to minimize non-specific priming during amplification, we used touchdown PCR as described previously [94]. The annealing step was carried out at $5^{\circ} \mathrm{C}$ above and $3^{\circ} \mathrm{C}$ below the primer's melting temperature as shown in the Additional file 7 . The touchdown thermal profile consisted of a 15 min heat activation step at $95^{\circ} \mathrm{C}$, followed by 10 cycles at $94^{\circ} \mathrm{C}$ for $30 \mathrm{sec}$, a ramp of $-0.8^{\circ} \mathrm{C}$ per cycle (see Additional file 7 for max and min temperatures) for $30 \mathrm{sec}, 72^{\circ} \mathrm{C}$ for $1 \mathrm{~min}$. Additional $38 \mathrm{cycles}$ at $94^{\circ} \mathrm{C}$ for $30 \mathrm{sec}$, minimum annealing temperature (see Additional file 7) for $30 \mathrm{sec}, 72^{\circ} \mathrm{C}$ for $1 \mathrm{~min}$, and a final incubation at $72^{\circ} \mathrm{C}$ for $10 \mathrm{~min}$. All the PCR products were visualized using $2 \%$ TAE-agarose gels stained with ethidium bromide. The PCR product of one LM sample (TC110731) was sequenced to confirm identity.

\section{GeneChip ${ }^{\circledR}$ Medicago genome array labeling and hybridization}

The Affymetrix GeneChip ${ }^{\circledR}$ Medicago Genome Array (Affymetrix, Santa Clara, CA) was used for expression analysis. RNA from three independent biological repli- 
cates was analyzed for each treatment. $5 \mu \mathrm{g}$ of columnpurified total RNA were used for one-cycle eukaryotic target labeling. Targets were hybridized to the arrays; probe arrays were washed, stained and scanned according to the manufacturer's instructions (Affymetrix).

\section{GeneChip ${ }^{\circledR}$ data acquisition and analysis}

Data normalization between chips was conducted using Robust Multi-chip Average (RMA) [95]. Presence/absence call for each probe set was obtained using dCHIP [96]. Gene selections based on associative $t$-test [97] were made using MATLAB ${ }^{\circledast}$ (MathWorks, Natick, MA). Details of this method were presented previously [60]. A selection threshold of 2 for transcript ratios (where applicable) and a Bonferroni-correction $p$-value threshold of $1.14 \times 10^{-6}$ were used. False discovery rate of all significant genes was monitored with q-values obtained by EDGE software $[98,99]$.

\section{Authors' contributions}

SKG developed the laser microdissection method, carried out the laser microdissection and the RT-PCR analyses, and wrote the manuscript. HJ and PD generated the $M$. truncatula transgenic plant line used for the laser microdissection studies and HJ reviewed the manuscript. ITJ carried out the affymetrix chip experiments and YT analyzed the affymetrix array data. EBB developed the laser microdissection method and reviewed the manuscript. MKU participated in the affymetrix array experiments and reviewed the manuscript. $\mathrm{MJH}$ conceived the experiments and wrote the manuscript. All authors read and approved the final manuscript.

\section{Additional material}

\section{Additional file 1}

Genes showing differential expression in Medicago truncatula roots colonized by Glomus intraradices relative to mock-inoculated control roots.

Click here for file

[http://www.biomedcentral.com/content/supplementary/14712229-9-10-S1.xls]

\section{Additional file 2}

Probesets on the GeneChip ${ }^{\circledR}$ predicted to represent Glomus intraradices genes.

Click here for file

[http://www.biomedcentral.com/content/supplementary/14712229-9-10-S2.xls]

\section{Additional file 3}

M. truncatula pMtSCP1::GFP plant line used for laser microdissection. (a) M. truncatula pMtSCP1::GFP roots colonized by G. intraradices. (b) Mock-inoculated M. truncatula pMtSCP1::GFP roots. ( $c$ and e) Transverse sections of M. truncatula pMtSCP1::GFP mock-inoculated roots and ( $d$ and $f$ ) roots colonized by $\mathrm{G}$. intraradices.

Click here for file

[http://www.biomedcentral.com/content/supplementary/14712229-9-10-S3.tiff]

\section{Additional file 4}

Number of Medicago truncatula cortical cells obtained by laser microdissection and laser pressure catapulting, and aRNA yield after two rounds of linear RNA amplification.

Click here for file

[http://www.biomedcentral.com/content/supplementary/14712229-9-10-S4.xls]

\section{Additional file 5}

Analysis of the MtPT4 transcripts by RT-PCR. (A) RNA from LM cortical cells from mock-inoculated roots (LM-M) and M. truncatula/G. versiforme mycorrhizal roots (LM-GV). Glyceraldehyde 3-phosphate dehydrogenase (GDPD) was used as endogenous control. M. truncatula/ G. versiforme whole mycorrhizal root system (MtGV1) and M. truncatula/G. versiforme root pieces (MtGV2) samples were included as positive controls. (B) Location of oligonucleotide primers based on the ATG site of the MtPT4 (AY116210) coding sequence, 74-280 bp (MtPT4- $a$ ), 385-586 bp (MtPT4-b), 468-677 bp (MtPT4-c), and 1438-1545 bp (MtPT4-d).

Click here for file

[http://www.biomedcentral.com/content/supplementary/1471-

2229-9-10-S5.tiff]

\section{Additional file 6}

Laser microdissection of cortical cells from $\mathrm{M}$. truncatula roots. pMtSCP1::GFP mock-inoculated (1A-1D) roots or M.

truncatulapMtSCP1::GFP/G. versiforme mycorrhizal roots (2A-2D) were used for $L M$. Transverse sections of mock-inoculated roots $(1 \mathrm{~A})$ and mycorrhizal roots (2A) with outlined target cortical cells, path of laser ablation $(1 B, 2 B)$, target areas for laser pressure catapulting $(1 C, 2 C)$, and view after cell catapulting $(1 D, 2 D) . B a r=25 \mu \mathrm{m}$.

Click here for file

[http://www.biomedcentral.com/content/supplementary/14712229-9-10-S6.tiff]

\section{Additional file 7}

\section{Oligonucleotides used for RT-PCR.}

Click here for file

[http://www.biomedcentral.com/content/supplementary/14712229-9-10-S7.xls] 


\section{Additional file 8}

Sequence of TC86704 predicted to encode a G. versiforme ferritinlike protein. This TC is assembled from ESTs from a Glomus versiforme spore CDNA library. Several ESTs were sequenced and they assembled into TC85704 that represents almost the complete coding sequence of the gene. The predicted protein shares over 54\% amino acid identity with ferritin from Triatoma infestans, a blood sucking arthropod and 52\% identity with ferritin from Suberites domuncula, a marine sponge. The finding of a putative $\mathrm{G}$. versiforme ferritin-like gene is surprising because based on BLAST searches, sequences similar to this are not present in other fungi. In general fungi use diverse approaches to obtain and store iron including a range of siderophores such as ferricrocin or hydroxamate-type siderophores that are synthesize by non-ribosomal peptide synthetases [100-102].

Click here for file

[http://www.biomedcentral.com/content/supplementary/14712229-9-10-S8.doc]

\section{Acknowledgements}

Funding for this work was provided by a TRIAD Foundation award (to $\mathrm{MJH}$ ), The U.S. National Science Foundation (DBI-034397) to MJH, USDA CSREES-NRI (grant 2006-35300-17/43) to MKU and the Samuel Roberts Noble Foundation. The authors thank Dr. J. Liu for root tissue, Dr. M. ScanIon (Cornell University) for use of laser microdissection equipment and rotary microtome, Dr. V. Klink (Mississippi State University), P. Kankanala and Dr. B. Valent (Kansas State University), for helpful discussions.

\section{References}

I. Schüßler A, Schwarzott D, Walker C: A new fungal phylum, the Glomeromycota: phylogeny and evolution. Mycological Research 2001, 105:1414-142I.

2. Gehrig A, Schüßler A, Kluge M: Geosiphon pyriforme, a fungus forming endocytobiosis with Nostoc (Cyanobacteria) is an ancestral member of the Glomales: Evidence by SSU rRNA analysis. J Mol Evol 1996, 43:7I-8I.

3. Berbee ML, Taylor JW: The Mycota, Fungal Molecular Evolution: Gene Trees and Geologic Time Edited by: Mclaughlin JW, Mclaughlin EG, Lemke PA. NY: Springer-Verlag; 2000:229-246.

4. Smith SE, Read DJ, (eds): Mycorrhizal Symbiosis. San Diego, CA: Academic Press, Inc; 1997.

5. Heijden MGA van der, Klironomos JN, Ursic M, Moutoglis P, Streitwolf-Engel R, Boller T, Wiemken A, Sanders IR: Mycorrhizal fungal diversity determines plant biodiversity, ecosystem variability and productivity. Nature 1998, 396:69-72.

6. Heijden MGA van der, Scheublin TR: Functional traits in mycorrhizal ecology: their use for predicting the impact of arbuscular mycorrhizal fungal communities on plant growth and ecosystem functioning. New Phytol 2007, $174(2): 244-250$.

7. Kosuta S, Chabaud M, Lougnon G, Gough C, Dénarié J, Barker DG, Bécard G: A diffusible factor from arbuscular mycorrhizal fungi induces symbiosis-specific MtENODII expression in roots of Medicago truncatula. Plant Physiol 2003, I 3 I(3):952-962.

8. Akiyama K, Matsuzaki K-l, Hayashi H: Plant sesquiterpenes induce hyphal branching in arbuscular mycorrhizal fungi. Nature 2005, 435(7043):824-827.

9. Besserer A, Puech-Pagès $V$, Kiefer $P$, Gomez-Roldan $V$, Jauneau $A$, Roy S, Portais JC, Roux C, Bécard G, Séjalon-Delmas N: Strigolactones stimulate arbuscular mycorrhizal fungi by activating mitochondria. PLoS Biology 2006, 4(7): 1239-1247.

10. Endre G, Kereszt A, Kevel Z, Mihacea S, Kaló P, Kiss G: A receptor kinase gene regulating symbiotic nodule development. Nature 2002, 417:962-966.

II. Stracke S, Kistner C, Yoshida S, Mulder L, Sato S, Kaneko T, Tabata S, Sandal N, Stougaard J, Szcyglowski K, Parniske M: A plant receptor-like kinase required for both bacterial and fungal symbiosis. Nature 2002, 417:959-962.
12. Ané J-M, Kiss GB, Riely BK, Penmetsa RV, Oldroyd GED, Ayax C, Levy J, Debelle F, Baek J-M, Kaló P, Rosenberg C, Roe BA, Long SR, Dénarié J, Cook DR: Medicago truncatula DMII Required for Bacterial and Fungal Symbioses in Legumes. Science 2004, 303(5662): 1364-1367.

13. Imaizumi-Anraku H, Takeda N, Charpentier M, Perry J, Miwa H, Umehara Y, Kouchi H, Murakami Y, Mulder L, Vickers K, Pike J, Downie JA, Wang T, Sato S, Asamizu E, Tabata S, Yoshikawa M, Murooka Y, Wu G], Kawaguchi M, Kawasaki S, Parniske M, Hayashi M: Plastid proteins crucial for symbiotic fungal and bacterial entry into plant roots. Nature 2005, 433(7025):527-53I.

14. Mitra RM, Gleason CA, Edwards A, Hadfield J, Downie JA, Oldroyd GED, Long SR: A Ca2+/calmodulin-dependent protein kinase required for symbiotic nodule development: Gene identification by transcript-based cloning. Proceedings of the National Academy of Sciences of the United States of America 2004, $101(13): 4701-4705$.

15. Levy J, Bres C, Geurts R, Chalhoub B, Kulikova O, Duc G, Journet EP, Ané JM, Lauber E, Bisseling T, Dénarié J, Rosenberg C, Debelle F: A putative $\mathrm{Ca} 2+$ and calmodulin-dependent protein kinase required for bacterial and fungal symbioses. Science 2004, 303(5662): I $36 \mid-1364$.

16. Saito K, Yoshikawa M, Yano K, Miwa H, Uchida H, Asamizu E, Sato S, Tabata S, Imaizumi-Anraku H, Umehara Y, Kouchi H, Murooka Y, Szczyglowski K, Downie JA, Parniske M, Hayashi M, Kawaguchi M: NUCLEOPORIN85 is required for calcium spiking, fungal and bacterial symbioses, and seed production in Lotus japonicus. Plant Cell 2007, 19(2):610-624.

17. Kanamori N, Madsen LH, Radutoiu S, Frantescu M, Quistgaard EMH, Miwa H, Downie JA, James EK, Felle HH, Haaning LL, Jensen TH, Sato $S$, Nakamura $Y$, Tabata S, Sandal N, Stougaard J: A nucleoporin is required for induction of $\mathrm{Ca} 2+$ spiking in legume nodule development and essential for rhizobial and fungal symbiosis. Proceedings of the National Academy of Sciences of the United States of America 2006, 103(2):359-364.

18. Chen $\mathrm{C}$, Gao M, Liu J, Zhu H: Fungal symbiosis in rice requires an ortholog of a legume common symbiosis gene encoding a $\mathrm{Ca2+/Calmodulin-dependent} \mathrm{protein} \mathrm{kinase.} \mathrm{Plant} \mathrm{Physiol} \mathrm{2007,}$ 145:1619-1628.

19. Markmann K, Giczey G, Parniske M: Functional adaptation of a plant receptor-kinase paved the way for the evolution of intracellular root symbioses with bacteria. PLoS Biology 2008, 6(3):497-506.

20. Parniske M: Intracellular accommodation of microbes by plants: a common developmental program for symbiosis and disease? Curr Opin Plant Biol 2000, 3:320-328.

21. Kistner C, Parniske M: Evolution of signal transduction in intracellular symbiosis. Trends Plant Sci 2002, 7(I I): I360-I 385.

22. Bonfante-Fasolo P: Anatomy and morphology of VA mycorrhizae. In VA Mycorrhizae Edited by: Powell CL, Bagyaraj DJ. Boca Raton, Florida: CRC Press; 1984:5-33.

23. Gianinazzi-Pearson V: Plant cell responses to arbuscular mycorrhiza fungi: Getting to the roots of the symbiosis. Plant Cell 1996, 8:187|-1883.

24. Genre $A$, Bonfante $P$ : Actin versus tubulin configuration in arbuscule-containing cells from mycorrhizal tobacco roots. New Phytol 1998, 140:745-752.

25. Genre A, Bonfante P: Cytoskeleton-related proteins in tobacco mycorrhizal cells: g-tubulin and clathrin localisation. Eur J Histochem 1999, 43:105-III.

26. Genre A, Chabaud M, Faccio A, Barker DG, Bonfante P: Prepenetration apparatus assembly precedes and predicts the colonization patterns of arbuscular mycorrhizal fungus within the root cortex of both Medicago truncatula and Daucus carota. Plant Cell 2008, 20: I407-I420.

27. Blancaflor EB, Zhao LM, Harrison MJ: Microtubule organization in root cells of Medicago truncatula during development of an arbuscular mycorrhizal symbiosis with Glomus versiforme. Protoplasma 2001, 217(4): 154-165.

28. Harrison MJ, Dewbre GR, Liu J: A phosphate transporter from Medicago truncatula involved in the acquisition of phosphate released by arbuscular mycorrhizal fungi. Plant Cell 2002, | 4:24|3-2429.

29. Govindarajulu M, Pfeffer PE, Jin HR, Abubaker J, Douds DD, Allen JW, Bucking $H$, Lammers PJ, Shachar-Hill Y: Nitrogen transfer in the 
arbuscular mycorrhizal symbiosis. Nature 2005, 435(7043):819-823.

30. Jin H, Pfeffer PE, Douds DD, Piotrowski E, Lammers PJ, Shachar-Hill $Y$ : The uptake, metabolism, transport and transfer of nitrogen in an arbuscular mycorrhizal symbiosis. New Phytol 2005, 168(3):687-696

31. Cruz C, Egsgaard H, Trujillo C, Ambus P, Requena N, Martins-Loucao MA, Jakobsen I: Enzymatic evidence for the key role of arginine in nitrogen translocation by arbuscular mycorrhizal fungi. Plant Physiol 2007, 144(2):782-792.

32. Cox G, Sanders F: Ultrastructure of the host-fungus interface in a vesicular-arbuscular mycorrhiza. New Phytol 1974, 73:90I-912

33. Alexander T, Meier R, Toth R, Weber HC: Dynamics of arbuscule development and degeneration in mycorrhizas of Triticum aestivum $\mathrm{L}$. and Avena sativa $\mathrm{L}$. with reference to Zea mays $\mathrm{L}$. New Phytol 1988, I I 0:363-370.

34. Gianinazzi-Pearson V, Gianinazzi S: Morphological integration and functional compatibility between symbionts in vesiculararbuscular endomycorrhizal associations. In Cell to Cell Signals in Plant, Animal and Microbial Symbiosis Edited by: Scannerini S, Smith DC, Bonfante-Fasolo P, Gianinazzi-Pearson V. Berlin: Springer-Verlag; 1988:73-84.

35. Güimil S, Chang H-S, Zhu T, Sesma A, Osbourn A, Roux C, loannidis V, Oakeley EJ, Docquier M, Descombes P, Briggs SP, Paszkowski U: Comparative transcriptomics of rice reveals an ancient pattern of response to microbial colonization. Proceedings of the National Academy of Sciences of the United States of America 2005, 1 02(22):8066-8070.

36. Liu J, Blaylock L, Endre G, Cho J, Town CD, VandenBosch K, Harrison M): Transcript profiling coupled with spatial expression analyses reveals genes involved in distinct developmental stages of the arbuscular mycorrhizal symbiosis. Plant Cell 2003 15:2106-2123.

37. Küster H, Hohnjec N, Krajinski F, El Yahyaoui F, Manthey K, Gouzy J, Dondrup M, Meyer F, Kalinowski J, Brechenmacher L, van Tuinen D, Gianinazzi-Pearson V, Pühler A, Gamas P, Becker A: Construction and validation of CDNA-based Mt6k-RIT macro- and microarrays to explore root endosymbioses in the model legume Medicago truncatula. Journal of Biotechnology 2004, I 08(2):95-I I 3 .

38. Hohnjec N, Vieweg MF, Pühler A, Becker A, Küster H: Overlaps in the transcriptional profiles of Medicago truncatula roots inoculated with two different Glomus fungi provide insights into the genetic program activated during arbuscular mycorrhiza. Plant Physiol 2005, 137(4):|283-|30|.

39. Liu J, Maldonado-Mendoza IE, Lopez-Meyer M, Cheung F, Town CD, Harrison MJ: The arbuscular mycorrhizal symbiosis is accompanied by local and systemic alterations in gene expression and an increase in disease resistance in the shoots. The Plant Journal 2007, 50:529-544.

40. Brechenmacher L, Weidmann S, van Tuinen D, Chatagnier O, Gianinazzi $S$, Franken $P$, Gianinazzi-Pearson V: Expression profiling of up-regulated plant and fungal genes in early and late stages of Medicago truncatula - Glomus mosseae interactions. Mycorrhiza 2004, I 4(4):253-262.

4I. Weidmann S, Sanchez-Calderon L, Descombin J, Chatagnier O, Gianinazzi S, Gianinazzi-Pearson V: Fungal elicitation of signal transduction related plant genes precedes mycorrhiza establishment and requires the DMI 3 gene in Medicago truncatula. Molecular Plant Microbe Interactions 2004, 17:1385-1393.

42. Wulf A, Manthey K, Doll J, Perlick AM, Linke B, Bekel T, Meyer F, Franken $P$, Küster $H$, Krajinski $F$ : Transcriptional changes in response to arbuscular mycorrhiza development in the model plant Medicago truncatula. Mol Plant-Microbe Interact 2003, I6(4):306-3।4.

43. Manthey K, Krajinski F, Hohnjec N, Firnhaber C, Pühler A, Perlick $\mathrm{AM}$, Küster $\mathrm{H}$ : Transcriptome profiling in root nodules and arbuscular mycorrhiza identifies a collection of novel genes induced during Medicago truncatula root endosymbioses. Mol Plant-Microbe Interact 2004, I7(10): 1063-1077.

44. Frenzel A, Manthey K, Perlick AM, Meyer F, Pühler A, Küster H, Krajinski F: Combined transcriptome profiling reveals a nove family of arbuscular mycorrhizal-specific Medicago truncatula lectin genes. Mol Plant-Microbe Interact 2005, I 8(8):77|-782.

45. Harrison Mj: Signaling in the arbuscular mycorrhizal symbiosis. Annual reviews of Microbiology 2005, 59:19-42.
46. Küster H, Vieweg MF, Manthey K, Baier MC, Hohnjec N, Perlick AM: Identification and expression regulation of symbiotically activated legume genes. Phytochemistry 2007, 68(I):8-18.

47. Emmert-Buck MR, Bonner RF, Smith PD, Chuaqui RF, Zhuang ZP, Goldstein SR, Weiss RA, Liotta LA: Laser capture microdissection. Science 1996, 274(5289):998-I00I.

48. Luo L, Salunga RC, Guo HQ, Bittner A, Joy KC, Galindo JE, Xiao HN Rogers KE, Wan JS, Jackson MR, Erlander MG: Gene expression profiles of laser-captured adjacent neuronal subtypes. Nature Medicine 1999, 5(I): 1 I7-I22

49. Asano T, Masumura T, Kusano H, Kikuchi S, Kurita A, Shimada H, Kadowaki K-i: Construction of a specialized cDNA library from plant cells isolated by laser capture microdissection: toward comprehensive analysis of the genes expressed in the rice phloem. Plant / 2002, 32(3):40 I-408

50. Nakazono M, Qiu F, Borsuk LA, Schnable PS: Laser-capture microdissection, a tool for the global analysis of gene expression in specific plant cell types: Identification of genes expressed differentially in epidermal cells or vascular tissues of maize. Plant Cell 2003, I 5(3):583-596.

5I. Kerk NM, Ceserani S, Tausta L, Sussez IM, Nelson TM: Laser capture microdissection of cells from plant tissues. Plant Physiol 2003, 132:27-35

52. Day RC, McNoe LA, Macknight RC: Transcript analysis of laser microdissected plant cells. Physiologia Plantarum 2007, I 29(2):267-282.

53. Ramsay K, Wang ZH, Jones MGK: Using laser capture microdissection to study gene expression in early stages of giant cells induced by root-knot nematodes. Molecular Plant Pathology 2004, 5(6):587-592

54. Klink VP, Alkharouf N, MacDonald M, Matthews B: Laser capture microdissection (LCM) and expression analyses of Glycine max (soybean) syncytium containing root regions formed by the plant pathogen Heterodera glycines (soybean cyst nematode). Plant Mol Biol 2005, 59(6):965-979.

55. Klink VP, Overall CC, Alkharouf NW, MacDonald MH, Matthews BF: Laser capture microdissection (LCM) and comparative microarray expression analysis of syncytial cells isolated from incompatible and compatible soybean (Glycine max) roots infected by the soybean cyst nematode (Heterodera glycines). Planta 2007, 226(6): I389-1409.

56. Ithal N, Recknor J, Nettleton D, Maier T, Baum TJ, Mitchum MG: Developmental transcript profiling of cyst nematode feeding cells in soybean roots. Mol Plant-Microbe Interact 2007, 20(5):5I 0-525.

57. Ithal N, Recknor J, Nettleton D, Hearne L, Maier T, Baum TJ, Mitchum MG: Parallel genome-wide expression profiling of host and pathogen during soybean cyst nematode infection of soybean. Mol Plant-Microbe Interact 2007, 20:293-305.

58. Tang WH, Coughlan S, Crane E, Beatty M, Duvick J: The application of laser microdissection to in planta gene expression profiling of the maize anthracnose stalk rot fungus Colletotrichum graminicola. Mol Plant-Microbe Interact 2006, I ( (I I): I240-I250.

59. Balestrini R, Gomez-Ariza J, Lanfranco L, Bonfante P: Laser microdissection reveals that transcripts for five plant and one fungal phosphate transporter genes are contemporaneously present in arbusculated cells. Mol Plant-Microbe Interact 2007, 20(9): $1055-1062$

60. Benedito VA, Torres-Jerez I, Murray JD, Andriankaja A, Allen S, Kakar K, Wandrey M, Verdier J, Zuber H, Ott T, Moreau S, Niebel A, Frickey T, Weiller G, He J, Dai X, Zhao PX, Tang Y, Udvardi MK: A gene expression atlas of the model legume Medicago truncatula. The Plant Journal 2008, 55(3):504-513.

61. Baena-Gonzalez E, Rolland F, Thevelein JM, Sheen J: A central integrator of transcription networks in plant stress and energy signalling. Nature 2007, 448(7 I 56):938-U9I0.

62. Kaló P, Gleason C, Edwards A, Marsh J, Mitra RM, Hirsch S, Jakab J Sims S, Long SR, Rogers J, Kiss GB, Downie JA, Oldroyd GED: Nodulation signaling in legumes requires NSP2, a member of the GRAS family of transcriptional regulators. Science 2005, 308(5729): 1786-1789.

63. Smit P, Raedts J, Portyanko V, Debelle F, Gough C, Bisseling T, Geurts R: NSP I of the GRAS protein family is essential for rhizobial Nod factor-induced transcription. Science 2005, 308(5729): |789-|79|. 
64. Drissner D, Kunze G, Callewaert N, Gehrig P, Tamasloukht M, Boller T, Felix G, Amrhein N, Bucher M: Lyso-phosphatidylcholine is a signal in the arbuscular mycorrhizal symbiosis. Science 2007 , 3 I 8(5848):265-268.

65. Arrighi JF, Barre A, Ben Amor B, Bersoult A, Soriano LC, Mirabella R, de Carvalho-Niebel F, Journet EP, Ghérardi M, Huguet T, Geurts R, Dénarié J, Rougé P, Gough C: The Medicago truncatula lysine motif-receptor-like kinase gene family includes NFP and new nodule-expressed genes. Plant Physiol 2006, I 42:265-279.

66. Ben Amor B, Shaw SL, Oldroyd GED, Maillet F, Penmetsa RV, Cook D, Long SR, Denarie J, Gough C: The NFP locus of Medicago truncatula controls an early step of Nod factor signal transduction upstream of a rapid calcium flux and root hair deformation. Plant J 2003, 34(4):495-506.

67. Walker C, Schussler A: Nomenclatural clarification and new taxa in the Glomeromycota. Mycoloogical Research 2004, 1 08:98I-982.

68. Maldonado-Mendoza IE, Dewbre GR, van Buuren ML, Versaw WK Harrison MJ: Methods to estimate the proportion of plant and fungal RNA in an arbuscular mycorrhiza. Mycorrhiza 2002, I 2:67-74.

69. Steedman HF: Polyester wax; a new ribbon embedding medium for histology. Nature 1957, I 79: I 345-I 348.

70. Steedman HF: Ester Wax 1960 - a Histological Embedding Medium. Quarterly Journal of Microscopical Science 1960, I $01(4): 459-462$

7I. Steedman HF: Tropical Ester Wax 1960. Quarterly Journal of Microscopical Science 1960, I 0 I:463-464.

72. Lenoir G, Williamson P, Holthuis JC: On the origin of lipid asymmetry: the flip side of ion transport. Current Opinion in Chemical Biology 2007, I I (6):654-66 I.

73. Balhadere PV, Talbot NJ: PDEI encodes a P-type ATPase involved in appressorium-mediated plant infection by the rice blast fungus Magnaporthe grisea. Plant Cell 200I, I 3(9): | 987-2004

74. Peng JR, Carol P, Richards DE, King KE, Cowling RJ, Murphy GP, Harberd NP: The Arabidopsis GAl gene defines a signaling pathway that negatively regulates gibberellin responses. Genes \& Development 1997, I I:3194-3205.

75. Silverstone AL, Ciampaglio CN, Sun TP: The Arabidopsis RGA gene encodes a transcriptional regulator repressing the gibberellin signal transduction pathway. Plant Cell 1998 10:155-169.

76. Laurenzio Ld, Wysocka-Diller J, Malamy JE, Pysh L, Helariutta Y, Freshour G, Hahn MG, Feldmann KA, Benfey PN: The SCARECROW gene regulates an asymmetric cell division that is essential for generating the radial organization of the Arabidopsis root. Cell 1996, 86:423-433.

77. Bolle C: The role of GRAS proteins in plant signal transduction and development. Planta 2004, 2 I 8:683-692.

78. Madsen EB, Madsen LH, Radutoiu S, Olbryt M, Rakwalska M, Szczyglowski K, Sato S, Kaneko T, Tabata S, Sandal N, Stougaard J: A receptor kinase gene of the LysM type is involved in legume perception of rhizobial signals. Nature 2003 425(6958):637-640.

79. Radutoiu S, Madsen LH, Madsen EB, Felle HH, Umehara $Y$, Gronlund M, Sato S, Nakamura Y, Tabata S, Sandal N, Stougaard J: Plant recognition of symbiotic bacteria requires two LysM receptorlike kinases. Nature 2003, 425(6958):585-592.

80. Limpens E, Franken C, Smit P, Willemse J, Bisseling T, Geurts R: LysM domain receptor kinases regulating rhizobial Nod factorinduced infection. Science 2003, 302(5645):630-633.

81. Bateman A, Bycroft $M$ : The structure of a Lys $M$ domain from $E$. coli membrane-bound lytic murein transglycosylase D (MItD). J Mol Biol 2000, 299: I | |3- I | I9.

82. Lerouge P, Roche P, Faucher C, Maillet F, Truchet G, Prome JC, Dénarié J: Symbiotic host-specificity of Rhizobium meliloti Is determined by a sulfated and acylated glucosamine oligosaccharide signal. Nature 1990, 344:78I-784.

83. Spaink HP, Sheeley DM, Vanbrussel AAN, Glushka J, York WS, Tak T, Geiger O, Kennedy EP, Reinhold VN, Lugtenberg BJ): A novel highly unsaturated fatty-acid moiety of lipo-oligosaccharide signals determines host specificity of Rhizobium. Nature 1991, 354: $125-130$.
84. Schliemann W, Ammer F, Strack D: Metabolite profiling of mycorrhizal roots of Medicago truncatula. Phytochemistry 2007, 69: II2-146.

85. Jones A, Davies HM, Voelker TA: Palmitoyl-acyl carrier potein (Acp) thioesterase and the evolutionary origin of plant acylacp thioesterases. Plant Cell 1995, 7:359-37I.

86. Trepanier M, Bécard G, Moutoglis P, Willemot C, Gagne S, Avis T], Rioux JA: Dependence of arbuscular-mycorrhizal fungi on their plant host for palmitic acid synthesis. Appl Environ Microbiol 2005, 7 I(9):534 I-5347.

87. Trieu AT, Harrison MJ: Rapid transformation of Medicago truncatula: regeneration via shoot organogenesis. Plant Cell Rep 1996, I6:6-II.

88. Javot H, Harrison MJ: Agrobacterium-mediated transformation of $M$. truncatula. The Medicago truncatula Handbook 2006:25-29.

89. St-Arnaud M, Hamel C, Vimard B, Caron M, Fortin JA: Enhanced hyphal growth and spore production of the arbuscular mycorrhizal fungus Glomus intraradices in an in vitro system in the absence of host roots. Mycol Res 1996, I00(3):328-332.

90. Harrison MJ, Dixon RA: Isoflavonoid accumulation and expression of defense gene transcripts during the establishment of vesicular-arbuscular mycorrhizal associations in roots of Medicago truncatula. Mol Plant-Microbe Interact 1993, 6:643-654.

91. Liu J, Blaylock L, Harrison MJ: cDNA arrays as tools to identify mycorrhiza-regulated genes: identification of mycorrhizainduced genes that encode or generate signaling molecules implicated in the control of root growth. Can J Bot 2004, 82:II77-II85.

92. McGonigle TP, Miller MH, Evans DG, Fairchild GL, Swan JA: A new method that gives an objective measure of colonization of roots by vesicular-arbuscular mycorrhizal fungi. New Phytol 1990, I | 5:495-50|.

93. Rozen S, Skaletsky H: Primer3 on the WWW for general users and for biologist programmers. Methods Mol Biol 2000 , I32:365-386

94. Don RH, Cox PT, Wainwright BJ, Baker K, Mattick JS: Touchdown PCR to circumvent spurious priming during gene amplification. Nucl Acids Res 1991, 19:4008-4008.

95. Irizarry RA, Hobbs B, Collin F, Beazer-Barclay YD, Antonellis KJ, Scherf U, Speed TP: Exploration, normalization, and summaries of high density oligonucleotide array probe level data. Biostatistics 2003, 4(2):249-264.

96. Li C, Wong WH: Model-based analysis of oligonucleotide arrays: Expression index computation and outlier detection. Proceedings of the National Academy of Sciences of the United States of America 200I, 98(I):31-36.

97. Dozmorov I, Centola M: An associative analysis of gene expression array data. Bioinformatics 2003, I 9:204-2 I I.

98. Storey JD, Tibshirani R: Statistical significance for genomewide studies. Proceedings of the National Academy of Sciences of the United States of America 2003, 1 00:9440-9445

99. Leek JT, Monsen E, Dabney AR, Storey JD: EDGE: extraction and analysis of differential gene expression. Bioinformatics 2006, 22(4):507-508.

100. Johnson L: Iron and siderophores in fungal-host interactions. Mycological Research 2008, I 12:170-183.

10I. Oide S, Krasnoff SB, Gibson DM, Turgeon BG: Intracellular siderophores are essential for ascomycete sexual development in heterothallic Cochliobolus heterostrophus and homothallic Gibberella zeae. Eukaryotic Cell 2007, 6(8): |339-1353.

102. Oide S, Moeder W, Krasnoff S, Gibson D, Haas H, Yoshioka K, Turgeon BG: NPS6, encoding a nonribosomal peptide synthetase involved in siderophore-mediated iron metabolism, is a conserved virulence determinant of plant pathogenic ascomycetes. Plant Cell 2006, I 8( I 0):2836-2853. 